\title{
A Comparison of Mathematics Learning Approaches of Gifted and Non-Gifted Students *
}

\author{
Ahsen Seda Bulut ${ }^{\mathrm{a}}$, Avni Yıldız ${ }^{\mathrm{b}}$ and Serdal Baltacı ${ }^{\mathrm{c}}$ \\ ${ }^{a}$ Kırşehir Ahi Evran University, Vocational School of Social Sciences, Kırşehir/Turkey (ORCID: 0000-0003-2192-7799) \\ ${ }^{\mathbf{b}}$ Zonguldak Bülent Ecevit University, Ereğli Faculty of Education, Zonguldak/Turkey (ORCID: 0000-0002-6428-188X) \\ ${ }^{\mathbf{c}}$ Kırşehir Ahi Evran University, Faculty of Education, Kırşehir/Turkey (ORCID: 0000-0002-8652-4467)
}

Article History: Received: 30 January 2020; Accepted: 30 July 2020; Published online: 26 August 2020

\begin{abstract}
In this study, it was aimed to investigate the mathematics learning approaches of gifted students and successful students who were not diagnosed as gifted in terms of variables of giftedness, gender, grade level, parents' profession and education level. Descriptive research model, which is one of the general survey models, was used in the study. For the 2018-2019 academic years, a total of 239 6th, 7th and 8th grade students, 84 of whom were gifted students and 155 of whom were non-gifted students, participated into the study. Data on gifted students were collected from the Science and Arts Center of a province in the Central Anatolia region, while data on non-gifted students were collected from a secondary school in the same province. Students' mathematics learning approaches were determined by using the "Scale of Mathematics Learning Approaches". When the findings were examined, a significant differentiation was observed in favor of gifted students in the in-depth learning approach between gifted and non-gifted students. In addition, there is a significant difference in favor of female students in in-depth and strategic learning sub-dimensions among gifted students. When the mathematics learning approaches of gifted and non-gifted students were compared according to grade level, no significant difference was found in the 8th grade level average scores.
\end{abstract}

Keywords: Approaches to learning mathematics, gifted students, non-gifted students

DOI:10.16949/turkbilmat.682111

\begin{abstract}
Öz: Yapılan bu çalışmada üstün yetenekli ve üstün yetenekli tanısı konulmamış başarılı öğrencilerin matematik öğrenme yaklaşımlarının üstün yeteneklilik tanısı, cinsiyet, sınıf düzeyi, velinin mesleği ve öğrenim durumu değişkenleri açısından incelenmesi amaçlanmıştır. Araştırmada genel tarama modellerinden betimsel araştırma modeli kullanılmıştır. Araştırmaya 2018-2019 eğitim öğretim yılında 6., 7. ve 8. sınıfa devam eden 84'ü üstün yetenekli öğrenci, 155'i üstün yetenekli tanıs1 konulmamış öğrenci olmak üzere toplam 239 öğrenci katılmıştır. Üstün yetenekli öğrencilere ilişkin veriler İç Anadolu bölgesindeki bir ilin Bilim Sanat Merkezi'nden, üstün yetenekli tanısı konulmamış öğrencilere ilişkin veriler ise aynı ilde bulunan bir ortaokuldan toplanmıştır. Öğrencilerin matematik öğrenme yaklaşımları, "Matematik Öğrenme Yaklaşımları Ölçeği”" ile toplanmıştır. Bulgular incelendiğinde, üstün yetenekli ve normal öğrenciler arasında derinlemesine öğrenme yaklaşımında üstün yetenekliler lehine anlamlı bir farklılaşma gözlenmiştir. Ayrıca üstün yetenekli öğrenciler arasında derinlemesine ve stratejik öğrenme alt boyutlarında kız öğrenciler lehine anlamlı bir farklılık bulunmuştur. Öğrenme yaklaşımları sınıf düzeylerine göre incelendiğinde 8. sınıfta üstün yetenekli öğrenciler ile üstün yetenekli tanısı konulmamış öğrenciler arasında anlamlı bir farkl11ı olmadığı görülmüştür.
\end{abstract}

Anahtar Kelimeler: Matematik öğrenme yaklaşımları, üstün yetenekli öğrenciler, üstün yetenekli tanısı konulmamış öğrenciler

Türkçe sürüm için tıklayınız

\section{Introduction}

How learning takes place has always occupied our minds. In fact, this is because we have not been able to solve the entire working mechanism of brain yet. It is a learning process for the individual to perceive the stimuli in the outside world and interpret their perceptions in different ways and turn them into a unique product (Beydoğan, 2007; Von Glasersfeld, 1996). In this learning process, it can be said that learning approaches can take an important place when individual differences are taken into consideration. The concept of learning approaches used for the first time by Marton and Saljo (1976) was used to reveal how individuals understand a reading piece. Learning approach, which is also defined as the interaction between the student and the learning task (Ramsden, 2000), is also expressed as the tendency of the individual when learning a subject (Ekinci, 2009). Learning approach expresses the aim of the student in learning, the process the student passed while learning and how the student organizes learning (Spencer, 2003).

Since learning is a multidimensional concept, it can be thought that the methods affecting learning can be multiple and varied. Knowing one's learning approaches helps teachers find more effective and creative ways of organizing their teaching status (Biggs, 1999; Entwistle, 2000). For this reason, it may be necessary to determine 
the learning approaches of students in environments where teaching activities are carried out in order for students to learn. For this reason, as Özgür and Tosun (2012) stated, learning approaches are an issue to be taken into consideration and researched. Learning approaches depend on the student's attitude towards the subject and the level of readiness, the teacher's attitude towards the student and the teaching methods used (Sezgin \& Ellez, 2002). Learning approaches also differ according to the types such as the content of the curriculum, function, teaching methods and techniques, features of the learning environment, evaluation methods (Ekinci, 2009; Entwistle \& Smith, 2002).

Learning approaches are important for an efficient and effective learning (Y1ldı, 2015). For that reason, it is important to know how the student learns in order to understand what kind of student he is and to be able to guide him (Oğuz \& Karakuş, 2017). Considering that learning approaches affect the academic success of the learner (Öztaşkın, 2014), it is necessary to determine the factors that leads students to researching and questioning in the process of education in other words, that force students to use the superficial or in-depth approach in the educational process (Çolak, 2006). Moreover, when the researches on mathematics education are analyzed, it is seen that the focus is on determining the factors that affect students' mathematics achievement (Pourselami, Erfani \& Firoozfar, 2013; Zakaria \& Nordin, 2008). It can be said that one of these factors is students' mathematics learning approaches. Because when they know their students' mathematics learning approaches, mathematics teachers will review their own teaching activities and will be able to make effective instruction by guiding students towards them (Göktepe-Yıldız \& Özdemir, 2008). When we consider the learning approach as the student's way of processing information, the ways in which students deal with learning can be categorized into three groups as superficial learning approach, in-depth learning approach, and strategic learning approach (Marton \& Saljo, 1976).

In the in-depth learning approach; it is essential to understand the source of the information obtained, to know its usage areas and to establish a relationship between them (Darlington, 2011). It was emphasized that the main objectives of the students who preferred the in-depth learning approach were understanding, that the examination of the related components was realized for learning, and that this review was transformed into a harmonious whole through a process (Chan, 2003; Ramsden, 2000). Byrne, Flood and Willis (2009) also stated that individuals with in-depth learning approach will obtain high-level learning products. Curzon (2004) emphasized that with this learning approach, students can test by creating hypotheses and see the connections between the topics.

The approach in which the learning ability is stable, the belief that the information is precise and unchanging is dominant and the information is presented by the authority is called superficial learning approach (Chan, 2003). Biggs (2001) stated that students who prefer superficial learning approach use low level skills even in a learning activity that requires using high level cognitive skills. Superficial learning approach is focused on memorization, no relation is searched between concepts (Biggs, 2001; Trigwell \& Prosser, 1991). Byrne, Flood and Willis (2001) stated that students with superficial learning approach have failed to memorize the necessary knowledge to pass exams, tend to focus on individual parts without establishing integrity and distinguish examples from rules.

Students with a strategic learning approach that addresses the issue of learning with the intention of being successful do not intend to search and create meaning (Reid, Duvall \& Evans, 2007). Beydoğan (2007) says students who have this learning approach will try to get as high a grade as possible, they will prefer sources that will accelerate their perception by using various materials and in this way, it would be easier for them to learn. Entwistle (1995) stated that the most important feature of the strategic learning approach is that it benefits the organization both in terms of working methods and time management. Some of the studies on learning approaches are as follows:

In their study, Beşoluk and Önder (2010) concluded that prospective teachers at undergraduate level prefer superficial learning more often while master degree teachers prefer more in-depth learning approach. In Scouller's (1998) study, where the effect of assessment methods on learning approaches was investigated, it was concluded that students preferred the superficial learning approach when preparing for multiple-choice exams, and that students preferred the in-depth learning approach more in tasks where their higher-level thinking skills were measured. Birenbaum and Feldman (1998) as well, determined that students who adopt in-depth learning approach prefer open-ended questions that are more thought-provoking. For example, in a study specific to a field Lee, Johanson and Tsai (2008) conducted a study with high school students, they examined science learning approaches and determined that students with a constructivist approach to learning, had in-depth science learning approaches. Sezgin-Selçuk, Çalişkan and Erol (2007) aimed to determine the learning approaches of prospective physics teachers and to examine these learning approaches with variables such as gender, grade level, and academic success. As a result, it was determined that the prospective physics teacher candidates preferred the in-depth learning approach more than the superficial learning approach. Özkan and Sezgin-Selçuk (2014) aimed to determine the learning approaches that high school students adopt while learning the physics lesson. In conclusion, it was determined that students preferred in-depth and superficial learning approaches 
slightly above the middle level in the physics course and that learning approaches did not differ significantly according to their gender. Alemdağ (2015) also examined learning approaches according to some variables in his study with physical education teacher candidates. As a result of his research, he found significant differences in adopting the in-depth learning approach in terms of grade level. He also determined that there is a positive relationship between academic success and learning approach. Cano (2007), on the other hand, reached the conclusion that the students who showed an in-depth approach in their study with high school students had higher academic success. When the studies on primary school students are examined, for example in their studies aiming to determine the approaches of primary school students to learn science lesson; Çoban and Ergin (2008) determined that the superficial and in-depth learning approaches of the students were very close to each other and did not differ significantly in terms of gender. Belge-Can and Boz (2012) examined the relationship between primary school students' preferred learning approaches with gender and age. As a result of their research, it was seen that as the ages of the students increased, their level of adoption of the in-depth learning approach decreased, whereas in all grade levels, more in-depth learning approach was adopted. In addition, it was found that female students preferred the in-depth learning approach more than male students.

Regarding the determination of mathematics learning approaches, Chiu (2012) gathered his understanding of mathematics learning in five categories as constructivist, interpretive, objectivist, protecting the rights and interests of the nation and the utilitarian in his research with $5^{\text {th }}$ grade students. Matic, Matic and Katalenic (2013) determined that students of engineering faculties prefer strategic, in-depth and superficial learning approaches respectively in mathematics lessons. Darlington (2011) determined that students adopt the strategic learning approach more in their research on mathematics learning approaches with university students. İlhan, Çetin and Kılıç (2013) aimed to develop the scale of mathematics learning approaches in their studies with high school students and two factors such as deep and superficial learning approach were identified in this process. In his study, Göktepe-Yıldız (2019) examined the effect of design-based mathematics applications on the spatial abilities and 3-dimensional geometric thinking skills of $8^{\text {th }}$ grade students in determined dimensions. In addition, the researcher developed a measurement tool that measures learning approaches in mathematics lesson. As a result of the research, he determined that the students' spatial abilities differ significantly according to their mathematics learning approaches.

Although studies have increased in recent years, there are fewer studies in our country. (Belge-Can \& Boz, 2012; Beşoluk \& Önder, 2010; Çoban \& Ergin, 2008; Göktepe-Yıldız, 2019; İlhan, Çetin \& Kılıç, 2013; SezginSelçuk et. al., 2007). On the other hand, it is also stated that instead of examining the learning approaches in general, examining them specific to a field may provide more detailed information (Enwistle, 1997). As a result, as İlhan et al., (2013) stated, the evaluation of mathematics learning approaches by separating them from learning approaches in other fields leads to more appropriate determinations. However, when we look at the studies mentioned above on learning approaches, it is seen that the current studies are oriented towards different education levels and different courses, but studies specific to mathematics are few (Chiu, 2012; Darlington, 2011; Göktepe-Yıldız, 2019; İlhan, Çetin \& Kılıç, 2013; Matic, Matic \& Katalenic, 2013). As can be seen, even though the math learning approaches have been examined, no research has been found comparing the mathematics learning approaches of students who have been diagnosed as gifted and those who have not been diagnosed as gifted.

It is stated that school programs do not meet the educational needs of students who have been diagnosed with giftedness, and that programs should have versatile and creative features. (Baykoç, 2014; Kontaş, 2010; Palanc1, 2004). Students who have not been diagnosed as gifted may have more thoughts that mathematics can be incomprehensible, abstract, difficult and complex than gifted students. Because gifted students are more successful in challenging and complex tasks that require mental performance. (Stuart \& Beste, 2011). The features of gifted students enable them to learn more successfully and faster than students who have not been diagnosed as gifted (Ataman, 2004; Davis \& Rimm, 2004). Actually, with the determination of this kind of research, the necessary arrangements can be determined by preparing the necessary learning environments and in this way, desired successes can be achieved for both groups. Accordingly, it can be said that the comparison of these two groups can yield important results for the mathematics teaching processes of both groups. Likewise, when the studies conducted are examined, it can be seen that the students with and without a gifted diagnosis are compared through various variables. For example, Mills (1993) researched the personality and learning styles of gifted students in the field of mathematics and determined that there are personal differences between gifted students and those who are not diagnosed as gifted students. Y1ldı,, Baltac1, Kurak, and Güven (2012) compared the two groups in terms of using problem solving strategies and made suggestions to guide the education of gifted students by revealing that gifted students used more strategies. In their research, Altun and Yazic1 (2010) revealed that there were differences in the learning styles of both groups by using Dunn's learning styles inventory. Also, Arseven and Yeşiltaş (2016) determined that the learning styles of the two groups differed and that gifted students prefer the most "independent" and "competitive" learning styles, while students not diagnosed as gifted prefer the most "dependent" and "participant" learning styles. In this study, both groups attending secondary school will be compared in terms of math learning approaches. By determining the learning 
approaches in mathematics of a part of a population that makes up a small part of the population, both the picture of the current situation in gifted students will be taken and by making comparisons with students who are not diagnosed as gifted, there will be an opportunity to make some moves in the education of gifted students and students who have not been diagnosed as gifted.

The concept of giftedness is defined as people who perform at a high level compared to their peers in intelligence, leadership capacity or special academic fields (Horn, 2002; Ravenna, 2008; Renzulli, 1999). Therefore, the presence of future leaders, scientists and artists is directly proportional to the importance attached to the education of gifted students (Sisk, 1990). Therefore, early recognition of gifted individuals and development of their skills are two important issues. (Çapan, 2010). Renzulli and Reis (1985) stated that gifted children may need extensive educational opportunities that cannot be provided through normal programs. To meet this need, Science and Art Centers (BİLSEM), which was founded in our country in 1995, care about their differences, add aesthetics to scientific thoughts and behaviors, tries to ensure that students produce, solve problems and self-realize themselves (Bilsem Yönergesi, 2007). Sowell, Zeigler, Bergwell and Cartwright (1990) used the phrase "gifted in mathematics" to students who can demonstrate mathematical skills that older students can do. Holton and Gaffney (1994) stated that gifted students can think analytically, deductively or inductively while solving their math problems. It is obvious that the mathematics education given to gifted students is very important in revealing their such thinking processes. It can be said that thanks to the Science and Art Centers (BİLSEM) in our country, mathematics education of gifted students is given importance. The studies conducted with Science and Art Centers in our country were mostly based on different variables such as problem solving and metacognition (Aktepe \& Aktepe, 2009; Baltaci, Yildiz \& Güven, 2014; Boran \& Aslaner, 2008; Yildiz, Baltaci, Kurak \& Güven, 2012; Aytekin, Baltacı, \& Yıldız, 2017).

In this study, because it is aimed to compare the emerging situations in the study of mathematics learning approaches of gifted and non-gifted students, the research is thought to provide useful information to all relevant stakeholders and our education system. In this study, it was aimed to investigate the mathematics learning approaches of gifted students and successful students who were not diagnosed as gifted in terms of variables of giftedness, gender, grade level, parents' profession and education level. On the other hand, the findings obtained at the end of the research will be an opportunity to compare with the results of the studies on mathematics learning approaches. For this reason, the problem of the research is determined as "How did the successful students' mathematics learning approaches differ according to some variables whether they are diagnosed as gifted or not". Because, many variables such as age, gender, past experiences, class level, and success level affect the learning approaches (Göktepe-Yıldız \& Özdemir, 2018; Senemoğlu, 2011; Trigwell \& Prosser, 1991). For this reason, the research problem has been examined in detail according to the following variables too.

Within this scope, the sub-problems of the research are as follows:

1. What are the math learning approaches of students with and without a diagnosis of gifted students?

2. Is there a statistical difference in mathematics learning approaches according to the diagnosis of giftedness among students?

3. Is there a statistically significant difference in mathematics learning approaches of gifted and non-gifted students according to gender?

4. Is there a statistically significant difference in mathematics learning approaches of gifted and non-gifted students according to their grade levels?

5. Is there a statistically significant difference in mathematics learning approaches of gifted and non-gifted students according to the parent's profession?

6. Is there a statistically significant difference in mathematics learning approaches of gifted and non-gifted students according to the education level of parents?

\section{Method}

In this chapter; information about the model of the research, participants, data collection, research process and analysis are given.

\subsection{Model of Research}

In this study, descriptive research model was used because it was aimed to reach general evaluations by making comparisons about mathematics learning approaches of gifted students and those students who were not diagnosed as gifted. Descriptive research aims to describe an existing situation as it is without any experimental process (Karasar, 2006). In this study, causal comparison approach was also used, since the research problem was examined separately in terms of variables such as gender, grade level, parent occupation, and education level. Cohen and Manion (1994) stated in causal comparison studies that there will be at least two groups affected by the same situation in different ways, or two groups that are affected and not affected by the assumed situation and that these groups can be analyzed in terms of some variables in order to determine the possible causes and influences of the current situation. Investigations to determine the causes of an existing /naturally 
occurring situation or event and the variables that affect them or the consequences of an effect are causal comparison studies. (Büyüköztürk, Çakmak, Akgün, Karadeniz \& Demirel, 2008).

\subsection{Participants}

A total of 239 students, 84 of whom are gifted students, 155 students who have not been diagnosed as gifted attending the $6^{\text {th }}, 7^{\text {th }}$ and $8^{\text {th }}$ grades participated in the study in the 2018-2019 academic year. Data on gifted students were collected from the Science and Arts Center of a province in the Central Anatolia region, and data on students with no gifted diagnoses were collected from a secondary school in the same province. In terms of academic success, the closest school to students in BILLSEM were tried to be chosen. The reason for choosing students close to each other as academic success is to determine whether the diagnosis of giftedness among successful students will make a difference on learning approaches. While choosing a school, all public schools in the province where the research was conducted were ranked according to the average of placement in high schools and the most successful school was chosen. Thus, the criterion sampling was one of the sampling methods for the selection of the public school. Here, school success was taken as a criterion.

Table 1. Descriptive statistics on the number of students participating in the research

\begin{tabular}{|c|c|c|c|c|c|c|}
\hline \multirow{5}{*}{ Gifted students } & Grade level & & 6th & 7th & 8th & Total \\
\hline & Gender & Female & 23 & 15 & 9 & 47 \\
\hline & & Male & 15 & 9 & 13 & 37 \\
\hline & Total & & 38 & 24 & 22 & 84 \\
\hline & $\mathrm{f}(\%)$ & & 45,24 & 28,57 & 26,19 & 100 \\
\hline \multirow{5}{*}{$\begin{array}{l}\text { Non-Gifted } \\
\text { students }\end{array}$} & Gender & & 46 & 24 & 16 & 86 \\
\hline & & Female & & & & \\
\hline & & Male & 22 & 32 & 15 & 69 \\
\hline & Total & & 68 & 56 & 31 & 155 \\
\hline & $\mathrm{f}(\%)$ & & 43,87 & 36,13 & 20 & 100 \\
\hline
\end{tabular}

As seen in the demographic characteristics of the students in Table 1 regarding gender, grade level and giftedness, 133 female (55.6\%) and 106 (44.4\%) male students participated in the study. 47 (55.9\%) of the students who are diagnosed as gifted are girls and $37(44.1 \%)$ are boys. The distribution of these students by grade level is as; $38(45.24 \%)$ students in the $6^{\text {th }}$ grade, $24(28.57 \%)$ students in the $7^{\text {th }}$ grade and $22(26.19 \%)$ students in the $8^{\text {th }}$ grade. It is understood that $55.4 \%$ of the students who are not diagnosed with gifted are girls and $44.6 \%$ are boys. Considering the distribution by grade level; There are $68(43.87 \%)$ students from the $6^{\text {th }}$ grade, $56(36.13 \%)$ from the $7^{\text {th }}$ grade and $31(20 \%)$ students from the $8^{\text {th }}$ grade.

\subsection{Data Collection Tools}

There are two remarkable studies (Göktepe-Yıldız, 2019; İlhan et al., 2013) that are aimed at determining learning approaches specifically for mathematics lesson. The scale developed by İlhan et al., (2013) has a twofactor structure in the form of a superficial and in-depth learning approach. Therefore, the scale of GöktepeY1ldiz (2019), which is suitable for middle school students, is used to measure all three factors in the form of a superficial, in-depth and strategic learning approach.

The Mathematics Learning Approach Scale developed by Göktepe-Yıldız (2019) consists of 33 items and three sub-dimensions as in-depth learning, superficial learning and strategic learning. The scores derived from the sub-dimensions of the scale are interpreted independently.

The high scores obtained from the sub-dimensions indicate that students tend to prefer that dimension in mathematics lesson more; low scores show that students tend to prefer that dimension in mathematics lessons less. For example, a student's "in-depth learning approach" is high while "strategic learning approach" may be low.

The scale is a 5-point Likert type scale as "I strongly disagree = 1" and "I strongly agree = 5". The three subfactors explain $41.048 \%$ of the whole variance. This rate is acceptable (Scherer vd, 1988). Item factor load values vary between .323 and .713 (Göktepe-Yıldız \& Özdemir, 2018). When starting the analysis of this study, the skewness - kurtosis values of whether the data show a normal distribution were examined to decide which statistical tests to do first. Distortion $(-, 886)$ and kurtosis $(1,414)$ of the whole test; skew $(-, 959)$ and kurtosis $(, 293)$ for in-depth subdimension; distortion $(-1.085)$ and kurtosis $(, 847)$; for the strategic sub-dimension; superficial subscale, is as the form of skewness $(, 199)$ and kurtosis $(-, 512)$.

Göktepe-Y1ldiz (2019) determined the Cronbach Alpha internal consistency coefficient of the whole scale as .78. Then, the internal consistency coefficient for the in-depth learning approach sub-dimension was $.83, .83$ for the strategic learning approach, and .78 for the superficial learning approach. In this study, these coefficients 
were recalculated and the Cronbach Alpha reliability coefficient of the whole scale was found as .88. In the subdimensions, this number was found to be .89 for the in-depth learning approach and .90 for the strategic learning approach and .77 for the superficial learning approach. It can be said that this scale is sufficiently reliable since scales with a reliability coefficient of .70 and above are considered reliable (Fraenkel, Wallend \& Hyun, 2012).

\subsection{Data Analysis}

The researchers went to the chosen middle school located in BILSEM and the city center and explained the research to the institution administrators and the scale forms were applied to the students with the support of the institution administrators. Scale forms taken from students are systematically numbered and kept for analysis. The data of the research were analyzed by using SPSS 23.00 package program.

Firstly, whether the dependent variable is normally distributed at the level of the independent variable is examined while beginning the analysis to determine the statistical analysis to be performed to find out the differentiation status of mathematics learning approaches according to various variables (Kolmogrow-Smirnow $\mathrm{H}$ test). Giftedness diagnosis (K-S84=.075, p>.05; K-S155=.102, p>.05), gender (K-S133=.098, p>05; K$\mathrm{S} 106=.111$, p. >05), grade $(\mathrm{K}-\mathrm{S} 106=.106, \mathrm{p}>.05 ; \mathrm{K}-\mathrm{S} 80=.140, \mathrm{p}>.05 ; \mathrm{K}-\mathrm{S} 53=.065$, p >.05), mother's profession $(\mathrm{K}-\mathrm{S} 73=.062, \mathrm{p}>.05 ; \mathrm{K}-\mathrm{S} 29=.186, \mathrm{p}<.05 ; \mathrm{K}-\mathrm{S} 137=.114, \mathrm{p}>.05)$ father's profession $(\mathrm{K}-\mathrm{S} 111=.059$, p>.05; K$\mathrm{S} 110=.150, \mathrm{p}>.05 ; \mathrm{K}-\mathrm{S} 18=.115, \mathrm{p}<.05)$, mother's education level $(\mathrm{K}-\mathrm{S} 139=.136, \mathrm{p}>05 ; \mathrm{K}-\mathrm{S} 76=.084, \mathrm{p}>.05, \mathrm{~K}-$ $\mathrm{S} 24=.128, \mathrm{p}<.05)$, father's education level $(\mathrm{K}-\mathrm{S} 120=.120, \mathrm{p}>.05 ; \mathrm{K}-\mathrm{S} 91=.072, \mathrm{p}>.05, \mathrm{~K}-\mathrm{S} 28=.087, \mathrm{p}<.05)$ variables are in accordance with the test values, independent samples t-test for groups with normal distribution and for non-normal groups under the Mann-Whitney U test was utilized. Analysis of the data was evaluated at $\mathrm{p}<0.05$ significance level.

\section{Results}

In this section, mathematics learning approaches of students who are not diagnosed with gifted students and gifted students are reported for the overall scale according to the gifted students' grade levels, gender, parents' education level and parents' profession.

\subsection{Results Related to the First Sub-Problem}

Descriptive statistics of students' mathematics learning approaches are given in Table 2.

Table 2. Descriptive statistics of students' mathematics learning approaches

\begin{tabular}{cccccc}
\hline Type of students & Learning approaches & Min. & Max. & $\bar{X}$ & $S D$ \\
\hline \multirow{2}{*}{ Gifted students } & In-Depth & 21 & 55 & 44.50 & 8.96 \\
& Strategic & 19 & 55 & 43.72 & 8.77 \\
& Superficial & 18 & 55 & 33.30 & 8.38 \\
\hline \multirow{2}{*}{ Non-Gifted students } & In-Depth & 13 & 55 & 40.47 & 10.38 \\
& Strategic & 11 & 55 & 42.44 & 10.35 \\
& Superficial & 13 & 55 & 31.54 & 9.13 \\
\hline
\end{tabular}

Descriptive statistics about mathematics learning approaches of students with and without a diagnosis of giftedness are given in Table 2 below:

Since there are 11 items in each sub-dimension of the scale used, the minimum score that can be obtained for the sub-dimensions is 11 and the maximum score is 55. Accordingly, the middle score value was calculated as 33. In the findings related to which learning approach students prefer, the average scores for gifted individuals are listed as in-depth learning approach, strategic learning approach and superficial learning approach respectively. The in-depth and strategic learning approach score averages of the students in this group are above average. The superficial learning approach score average is approximately medium score. In line with these findings, it can be said that gifted students prefer in-depth and strategic learning approaches above the middle level and the superficial learning approach at the intermediate level. On the other hand, the average score of students with no gifted diagnoses from high to low respectively is as strategic learning approach, in-depth learning approach and superficial learning approach. As seen in Table 2, students who have not been diagnosed with gifted skills preferred the strategic and in-depth learning approach above the middle score, whereas they preferred the surface learning approach just below the medium score.

\subsection{Results Related to the Second Sub-Problem}

In order to examine whether there is a statistically significant difference between the mathematics learning approaches of the 84 gifted students who were diagnosed and 155 gifted students who participated in the study, the normality test was performed and because it showed a normal distribution t-test was utilized and shown in Table 3. 
Table 3. Independent samples t-test results regarding mathematics learning approaches according to the diagnosis of giftedness

\begin{tabular}{|c|c|c|c|c|c|c|}
\hline Learning approaches & Students diagnosis & $\bar{X}$ & $S D$ & $d f$ & $t$ & $p$ \\
\hline In-Depth Learning & Gifted & 4.04 & .94 & & & \\
\hline & Non- Gifted & 3.67 & .81 & 237 & -2.99 & $.003 *$ \\
\hline Strategic Learning & $\begin{array}{c}\text { Gifted } \\
\text { Non- Gifted }\end{array}$ & $\begin{array}{l}3.97 \\
3.85\end{array}$ & $\begin{array}{l}.79 \\
.94\end{array}$ & 237 & -.962 & .337 \\
\hline Superficial Learning & $\begin{array}{c}\text { Gifted } \\
\text { Non- Gifted }\end{array}$ & $\begin{array}{l}3.02 \\
2.86\end{array}$ & $\begin{array}{l}.83 \\
.76\end{array}$ & 237 & -1.46 & .143 \\
\hline
\end{tabular}

As a result of the analysis conducted to determine whether students' mathematics learning approaches differ according to the diagnosis of giftedness, a meaningful differentiation was observed in favor of gifted students in the in-depth learning approach between gifted and typical students $(t=-2,99, p<.05)$. In other words, gifted students prefer learning more in-depth approach than other students while learning mathematics. There was no significant difference between the mean scores in strategic learning $(t=-, 96, p>.05)$ and superficial learning approaches $(\mathrm{t}=-1.46, \mathrm{p}>.05)$.

\subsection{Results Related to the Third Sub-Problem}

Independent samples t-test was performed according to the normality test result to determine the difference in mathematics learning approaches of the students who were diagnosed and gifted according to gender, and the results are presented in Table 4.

Table 4. t-test results of mathematics learning approaches by gender

\begin{tabular}{|c|c|c|c|c|c|c|c|}
\hline Student diagnosis & Learning approaches & Gender & $\bar{X}$ & $S D$ & $d f$ & $t$ & $p$ \\
\hline \multirow{6}{*}{ Gifted students } & In-Depth & Female & 4.23 & .704 & 82 & 2.40 & $.018^{*}$ \\
\hline & & Male & 3.81 & .891 & & & \\
\hline & Strategic & Female & 4.20 & .713 & 82 & 3.16 & $.002 *$ \\
\hline & & Male & 3.68 & .809 & & & \\
\hline & Superficial & Female & 3.03 & .762 & 82 & .01 & .991 \\
\hline & & Male & 3.02 & .773 & & & \\
\hline \multirow{6}{*}{$\begin{array}{l}\text { Non-Gifted } \\
\text { students }\end{array}$} & In-Depth & Female & 3.77 & .907 & 153 & 1.357 & .177 \\
\hline & & Male & 3.56 & .982 & & & \\
\hline & Strategic & Female & 4.00 & .877 & 153 & 2.127 & $.035^{*}$ \\
\hline & & Male & 3.68 & .993 & & & \\
\hline & Superficial & Female & 2.77 & .783 & 153 & -1.539 & .126 \\
\hline & & Male & 2.98 & .877 & & & \\
\hline
\end{tabular}

$* \mathrm{p}<.05$

As a requirement of the scale used, analysis was made for each 3 sub-dimensions. When the results in Table 4 are analyzed, there is a significant difference between gifted students according to gender variable in their subdimensions $(\mathrm{t}=2.40, \mathrm{p}<.05)$ and strategic learning $(\mathrm{t}=3.16, \mathrm{p}<.05)$. This difference is in favor of female students. In other words; gifted female students prefer more in-depth and strategic learning approaches than male students. In the superficial learning approach, there is no significant difference by gender. $(\mathrm{t}=, 01, \mathrm{p}>.05)$. Considering the analysis results of students who have not been diagnosed as gifted students, the mean scores of girls' in-depth and strategic learning approaches are higher than boys, and they are lower in superficial learning approaches. As a result of the analysis conducted to investigate whether this difference in scores was statistically significant among students, it was determined that the scores of female students were significantly higher than the boys only in the strategic learning approach $(t=2,12, p<.05)$. The difference in scores between girls and boys does not show a significant difference in in-depth and superficial learning.

\subsection{Results Related to the Fourth Sub-Problem}

According to the grade levels, normality test was performed for the analysis of whether mathematics learning approaches of students who were diagnosed and not diagnosed had changed and since it shows normal distribution, independent samples are analyzed with $t$ test and presented in Table 5. 
Table 5. Independent samples t-test results regarding mathematics learning approaches of students with / without giftedness according to grade levels

\begin{tabular}{|c|c|c|c|c|c|c|c|}
\hline Grade level & Learning approaches & Student diagnosis & $\bar{X}$ & $S D$ & $d f$ & $t$ & $p$ \\
\hline \multirow{6}{*}{6} & \multirow[t]{2}{*}{ In-Depth } & Gifted & 4.18 & .752 & \multirow[t]{2}{*}{104} & \multirow{2}{*}{-1.936} & \multirow[t]{2}{*}{.056} \\
\hline & & Non-Gifted & 3.84 & .915 & & & \\
\hline & \multirow{2}{*}{ Strategic } & Gifted & 4.09 & .799 & \multirow{2}{*}{104} & \multirow{2}{*}{-.036} & \multirow{2}{*}{.972} \\
\hline & & Non-Gifted & 4.08 & .873 & & & \\
\hline & \multirow{2}{*}{ Superficial } & Gifted & 2.94 & .726 & \multirow[b]{2}{*}{104} & \multirow{2}{*}{-2.218} & \multirow[b]{2}{*}{$.029 *$} \\
\hline & & Non-Gifted & 2.59 & .785 & & & \\
\hline \multirow{6}{*}{7} & In-Depth & Gifted & 4.16 & .583 & \multirow{2}{*}{78} & \multirow{2}{*}{-3.186} & \multirow{2}{*}{$.000^{*}$} \\
\hline & & Non-Gifted & 3.45 & 1.01 & & & \\
\hline & Strategic & Gifted & 4.02 & .781 & \multirow{2}{*}{78} & \multirow{2}{*}{-1.842} & \multirow{2}{*}{.069} \\
\hline & & Non-Gifted & 3.59 & 1.02 & & & \\
\hline & \multirow[t]{2}{*}{ Superficial } & Gifted & 3.25 & .820 & \multirow{2}{*}{78} & \multirow{2}{*}{379} & \multirow{2}{*}{.706} \\
\hline & & Non-Gifted & 3.32 & .768 & & & \\
\hline \multirow{5}{*}{8} & In-Depth & Gifted & 3.67 & 1.02 & \multirow{2}{*}{51} & \multirow{2}{*}{.167} & \multirow{2}{*}{.868} \\
\hline & & Non-Gifted & 3.71 & .800 & & & \\
\hline & Strategic & Gifted & 3.71 & .785 & \multirow{2}{*}{51} & \multirow{2}{*}{.524} & \multirow{2}{*}{.602} \\
\hline & & Non-Gifted & 3.83 & .822 & & & \\
\hline & Superficial & Gifted & 2.92 & .741 & 51 & -1.534 & .131 \\
\hline
\end{tabular}

*p<.05

In distribution of students according to grade level, there are 38 gifted and 68 normal students in the $6^{\text {th }}$ grade, 24 superior and 56 normal students in the $7^{\text {th }}$ grade, 22 superior and 31 normal students in the $8^{\text {th }}$ grade. When the t-test results of independent samples conducted to compare the math learning approaches of students who were diagnosed with giftedness and not according to grade level were examined, no significant difference was found in mean scores at the $8^{\text {th }}$ grade level. However, it is seen a significant difference in $7^{\text {th }}$ grade in-depth learning in favor of gifted students $(\mathrm{t}=-3,18, \mathrm{p}<.05)$ and in $6^{\text {th }}$ grade superficial learning approach in favor of gifted students $(\mathrm{t}=-2,21, \mathrm{p}<.05)$.

\subsection{Results Related to the Fifth Sub-Problem}

The mathematics learning approaches between the two groups were analyzed according to the parents' profession and the results are presented in table below. Table 6 and Table 7 compared the mathematics learning approaches of the students according to the profession of the mothers, Table 8 and Table 9 compared the mathematics learning approaches of the students who were diagnosed with /without giftedness according to the profession of the fathers. With the normal distribution of the groups, how the students' mathematical learning approaches changed according to the mother's profession were analyzed with independent samples t-test and presented in Table 6.

Table 6. $\mathrm{t}$-test results regarding mathematics learning approaches of students diagnosed with / without talent according to mother's profession

\begin{tabular}{|c|c|c|c|c|c|c|c|}
\hline & Learning approaches & Student diagnosis & $\bar{X}$ & $S D$ & $d f$ & $t$ & $p$ \\
\hline \multirow{5}{*}{ Public } & In-Depth & $\begin{array}{c}\text { Gifted } \\
\text { Non-Gifted }\end{array}$ & $\begin{array}{l}4.16 \\
3.62\end{array}$ & $\begin{array}{l}.730 \\
.749\end{array}$ & 71 & -3.073 & $.003 *$ \\
\hline & \multirow[t]{2}{*}{ Strategic } & Gifted & 3.99 & .869 & \multirow{2}{*}{71} & \multirow{2}{*}{.-705} & \multirow{2}{*}{.483} \\
\hline & & Non-Gifted & 3.86 & .651 & & & \\
\hline & \multirow{2}{*}{ Superficial } & Gifted & 3.08 & .772 & \multirow[b]{2}{*}{71} & \multirow{2}{*}{-1.575} & \multirow{2}{*}{.120} \\
\hline & & Non-Gifted & 2.77 & .881 & & & \\
\hline \multirow{6}{*}{ Not Work } & In-Depth & Gifted & 3.91 & .919 & \multirow{2}{*}{135} & \multirow{2}{*}{-1.086} & \multirow{2}{*}{.280} \\
\hline & \multirow{3}{*}{ Strategic } & Non-Gifted & 3.70 & .980 & & & \\
\hline & & Gifted & 3.93 & .732 & \multirow{2}{*}{135} & \multirow{2}{*}{-.401} & \multirow{2}{*}{640} \\
\hline & & Non-Gifted & 3.86 & 1.010 & & & \\
\hline & \multirow{2}{*}{ Superficial } & Gifted & 2.93 & .747 & \multirow[b]{2}{*}{135} & \multirow[b]{2}{*}{.060} & \multirow[b]{2}{*}{.952} \\
\hline & & Non-Gifted & 2.94 & .811 & & & \\
\hline
\end{tabular}

$* \mathrm{p}<.05$ 
Among the gifted students' mothers, the number of public employees is $43(51.20 \%)$ and the number of those who do not work is $34(40.47 \%)$. The number of the mothers of the students who have not been diagnosed with giftedness employed in public sector is 30 (19.35\%), and $103(66.46 \%)$ of the unemployed. Looking at the learning approaches of the students according to the mother's professions in Table 6 , the in-depth learning approach of the children whose mothers work in public differs statistically in favor of gifted students $(\mathrm{t}=-3,07$, $\mathrm{p}<.05)$. In other words, gifted individuals whose mother works in public prefer in-depth learning approaches more than normal students. In the strategic and superficial learning approaches, no significant difference was found among the students.

As a result of the analysis made for the students who are in the category of unemployed mothers, it is seen that there is no significant difference in any learning approach among these students. On the other hand, the averages of gifted students are higher than the other student group in their in-depth and strategic learning approach.

Learning approaches of the students whose mother's profession is "Private Sector" were determined by Mann-Whitney U test. Because 7 (8.33\%) mothers of gifted parents and 22 (14.19\%) mothers of parents of other groups are in this category and the data are not distributed normally. In this context, the relevant results are as in Table 7.

Table 7. Mann-Whitney U test results regarding mathematics learning approaches of students diagnosed with / without giftedness whose mothers are "Private Sector" employees

\begin{tabular}{|c|c|c|c|c|c|c|}
\hline Learning approaches & Student diagnosis & Rank average & Rank total & M-Whitney $U$ & $Z$ & $p$ \\
\hline \multirow{2}{*}{ In-Depth } & Gifted & 17.36 & 121.50 & \multirow{2}{*}{60.500} & \multirow{2}{*}{-.843} & \multirow{2}{*}{.399} \\
\hline & Non-Gifted & 14.25 & 313.50 & & & \\
\hline \multirow{2}{*}{ Strategic } & Gifted & 15.93 & 111.50 & \multirow{2}{*}{70.500} & \multirow{2}{*}{-.332} & \multirow{2}{*}{.740} \\
\hline & Non-Gifted & 14.70 & 323.50 & & & \\
\hline \multirow{2}{*}{ Superficial } & Gifted & 18.64 & 130.50 & \multirow{2}{*}{51.500} & \multirow{2}{*}{-1.302} & \multirow{2}{*}{.193} \\
\hline & Non-Gifted & 13.84 & 304.50 & & & \\
\hline
\end{tabular}

Table 7 presents data on mathematics learning approaches of students whose mothers are private sector employees. It has been observed that there is no statistical difference between the groups according to the mother's working status in the private sector in gifted and normal students' mathematics learning approaches.

Data on the father's profession are as follows:

Table 8. T-test results regarding math learning approaches of students diagnosed with / without giftedness according to father's profession

\begin{tabular}{|c|c|c|c|c|c|c|c|}
\hline & Learning approaches & Student diagnosis & $\bar{X}$ & $S D$ & $d f$ & $t$ & $p$ \\
\hline \multirow{6}{*}{ Public } & In-Depth & Gifted & 4.04 & .837 & \multirow{2}{*}{109} & \multirow{2}{*}{-2.828} & \multirow{2}{*}{$.006^{*}$} \\
\hline & & Non-Gifted & 3.59 & .838 & & & \\
\hline & Strategic & Gifted & 4.01 & .773 & \multirow{2}{*}{109} & \multirow{2}{*}{-1.307} & \multirow{2}{*}{.194} \\
\hline & \multirow{3}{*}{ Superficial } & Non-Gifted & 3.80 & .895 & & & \\
\hline & & Gifted & 2.92 & .710 & \multirow{2}{*}{109} & \multirow{2}{*}{-1.735} & \multirow{2}{*}{.086} \\
\hline & & Non-Gifted & 2.67 & .778 & & & \\
\hline \multirow{6}{*}{ Private sector } & In-Depth & Gifted & 4.03 & .828 & \multirow{2}{*}{108} & \multirow{2}{*}{-1.484} & \multirow{2}{*}{.141} \\
\hline & & Non-Gifted & 3.71 & 1.037 & & & \\
\hline & Strategic & Gifted & 3.96 & .827 & \multirow[b]{2}{*}{108} & \multirow[b]{2}{*}{-.418} & \multirow{2}{*}{.677} \\
\hline & \multirow{3}{*}{ Superficial } & Non-Gifted & 3.87 & 1.017 & & & \\
\hline & & Gifted & 3.10 & .785 & \multirow{2}{*}{108} & \multirow{2}{*}{-.641} & \multirow{2}{*}{.573} \\
\hline & & Non-Gifted & 2.99 & .864 & & & \\
\hline
\end{tabular}

$* \mathrm{p}<.05$

While the number of fathers of gifted students working in the public sector is $51(60.71 \%)$, the number of those working in the private sector is $30(35.72 \%)$. The situation is as $60(38.71 \%)$ fathers working in the public sector and $80(51.61 \%)$ in the private sector among students with no gifted diagnosis. fathers of students who have not been diagnosed with giftedness is as $60(38.71 \%)$ working in the public sector and $80(51.61 \%)$ in the private sector. Looking at the learning approaches of the students according to the father's professions in Table 8 , the in-depth learning approach of the children whose fathers work in the public sector differs statistically in favor of gifted students $(\mathrm{t}=-2.82, \mathrm{p}<.05)$.

The learning approaches of the students whose father's profession is in the "Not Working" category were also determined by the Mann-Whitney U test. 3 (3.57\%) fathers from gifted parents and 15 fathers (9.68) from groups 
are in this category and the data are not normally distributed. In this context, the relevant results are as in Table 9.

Table 9. Mann-Whitney U test results regarding math learning approaches of students diagnosed with/ without giftedness in "Not Working" category

\begin{tabular}{ccccccc}
\hline Learning Approaches & Students diagnosis & Rank average & Rank total & M-Whitney $U$ & $Z$ & $p$ \\
\hline In-Depth & Gifted & 12.00 & 36.00 & 15.000 & -.892 & .373 \\
& Non-Gifted & 9.00 & 135.00 & & & \\
Strategic & Gifted & 7.17 & 21.50 & 15.500 & -.832 & .405 \\
& Non-Gifted & 9.97 & 149.50 & & -1.958 & .050 \\
Superficial & Gifted & 15.00 & 45.00 & 6.000 & & \\
& Non-Gifted & 8.40 & 126.00 & & &
\end{tabular}

As stated in Table 9, there is no significant difference in mathematics learning approaches of students whose father is unemployed.

It can be seen from the 4 analyzes above made according to parents' professions between the two groups that there is a significant difference in favor of gifted among the gifted and normal children whose mothers and fathers work in public sector.

\subsection{Results Related to the Sixth Sub-Problem}

Considering the distribution of education levels of mothers of gifted students, 24 people (28.57\%) are high school graduates and lower, $40(47.62 \%)$ are university graduates. Education levels of mothers of students with no gifted diagnoses are 115 (74.19\%) high school and lower, 36 of them are $(23.22 \%)$ university graduates.

In Table 10 and Table 11, the educational status of the mothers from the parents of the students in the two groups were compared.

Table 10. Independent samples t-test results regarding mathematics learning approaches of students diagnosed with/ without giftedness according to the educational level of the mother

\begin{tabular}{|c|c|c|c|c|c|c|c|}
\hline Education level & Learning approaches & Student diagnosis & $\bar{X}$ & $S D$ & $d f$ & $t$ & $p$ \\
\hline \multirow{6}{*}{$\begin{array}{l}\text { High school } \\
\text { graduates and lower }\end{array}$} & In-Depth & Gifted & 3.87 & .858 & \multirow{2}{*}{137} & \multirow{2}{*}{-.876} & \multirow{2}{*}{.388} \\
\hline & & Non-Gifted & 3.69 & .958 & & & \\
\hline & Strategic & Gifted & 3.81 & .859 & \multirow{2}{*}{137} & \multirow{2}{*}{.277} & \multirow{2}{*}{.782} \\
\hline & & Non-Gifted & 3.87 & .956 & & & \\
\hline & \multirow[t]{2}{*}{ Superficial } & Gifted & 3.26 & .697 & \multirow{2}{*}{137} & \multirow{2}{*}{-1.426} & \multirow{2}{*}{.156} \\
\hline & & Non-Gifted & 3.00 & .812 & & & \\
\hline \multirow{6}{*}{ University } & In-Depth & Gifted & 4.03 & .876 & \multirow{2}{*}{74} & \multirow{2}{*}{-1.630} & \multirow{2}{*}{.107} \\
\hline & & Non-Gifted & 3.70 & .870 & & & \\
\hline & Strategic & Gifted & 4.01 & .764 & \multirow{2}{*}{74} & \multirow{2}{*}{-.668} & \multirow{2}{*}{.506} \\
\hline & \multirow{3}{*}{ Superficial } & Non-Gifted & 3.88 & .896 & & & \\
\hline & & Gifted & 2.78 & .744 & \multirow{2}{*}{74} & \multirow{2}{*}{-2.897} & \multirow{2}{*}{$.005^{*}$} \\
\hline & & Non-Gifted & 2.31 & 639 & & & \\
\hline
\end{tabular}

$* \mathrm{p}<.05$

When Table 10 is analyzed, according to the education level of the mothers, the results regarding the mathematics learning approaches of the two groups there is no significant difference observed between the two groups whose mother is in a high school graduate and lower education level. Considering the math learning approach of students whose mothers are university graduates, the scores of gifted students are significantly higher in the superficial learning approach compared to normal students $(t=-2,89, \mathrm{p}<, 05)$. Although the mean scores in the in-depth and strategic learning approaches are higher in favor of gifted students, this score difference does not create any statistically significant difference.

The learning approaches of the students whose mother's education level is "Post-graduate" are determined by Mann-Whitney $U$ test since the data is not distributed normally and presented in Table 11. This category includes $20(23.81 \%)$ mothers whose kids are gifted students and $4(2.59 \%)$ of the other group. 
Table 11. Mother's educational status Mann-Whitney U test results regarding mathematics learning approaches of students diagnosed with/without giftedness in the "Post-graduate" category

\begin{tabular}{ccccccc}
\hline Learning approaches & Student diagnosis & Rank average & Rank total & M-Whitney $U$ & $Z$ & $p$ \\
\hline In-Depth & Gifted & 13.88 & 277.50 & 12,500 & -2.140 & $\mathbf{. 0 3 2} *$ \\
& Non-Gifted & 5.63 & 22.50 & & & \\
Strategic & Gifted & 13.58 & 271.50 & 18,500 & -1.669 & .095 \\
& Non-Gifted & 7.13 & 28.50 & & -1.281 & .200 \\
Superficial & Gifted & 11.68 & 233.50 & 23,500 & \\
& Non-Gifted & 16.63 & 66.50 & & &
\end{tabular}

$* \mathrm{p}<.05$

As seen in table 11, comparing the children of mothers at "Post-graduate" level, the in-depth learning approach preference of gifted students is statistically different in favor of gifted to normal students $(\mathrm{z}=-2,14$, $\mathrm{p}<.05)$.

Data on the educational status of fathers are presented below. Considering the distribution of education levels of fathers of gifted students, 18 people $(21.44 \%)$ are high school and lower graduates, while $46(54.76 \%)$ are university graduates. Education levels of fathers of students with no gifted diagnosis were 102 people (65.80\%) high school and lower graduates, 45 people $(29.03 \%)$ university graduates. Independent samples t-test was applied in the analysis of data whose father's education level was high school graduate and lower and university level, as the group data showed normal distribution (Table 12).

Table 12. Independent samples t-test results regarding mathematics learning approaches of students diagnosed with/without giftedness according to father's educational status

\begin{tabular}{|c|c|c|c|c|c|c|c|}
\hline Education level & Learning approaches & Student diagnosis & $\bar{X}$ & $S D$ & $d f$ & $t$ & $p$ \\
\hline \multirow{3}{*}{$\begin{array}{l}\text { High school } \\
\text { graduates and lower }\end{array}$} & In-Depth & $\begin{array}{c}\text { Gifted } \\
\text { Non-Gifted }\end{array}$ & $\begin{array}{l}3.94 \\
3.65\end{array}$ & $\begin{array}{c}.766 \\
1.012\end{array}$ & 118 & -1.172 & .243 \\
\hline & Strategic & $\begin{array}{c}\text { Gifted } \\
\text { Non-Gifted }\end{array}$ & $\begin{array}{l}4.08 \\
3.81\end{array}$ & $\begin{array}{c}.572 \\
1.016\end{array}$ & 118 & -1.042 & .135 \\
\hline & Superficial & $\begin{array}{c}\text { Gifted } \\
\text { Non-Gifted }\end{array}$ & $\begin{array}{l}3.12 \\
3.01\end{array}$ & $\begin{array}{l}.801 \\
.871\end{array}$ & 118 & -.502 & .617 \\
\hline \multirow{3}{*}{ University } & In-Depth & $\begin{array}{c}\text { Gifted } \\
\text { Non-Gifted 1 }\end{array}$ & $\begin{array}{l}4.02 \\
3.72\end{array}$ & $\begin{array}{l}.842 \\
.792\end{array}$ & 89 & -1.764 & .081 \\
\hline & Strategic & $\begin{array}{c}\text { Gifted } \\
\text { Non-Gifted }\end{array}$ & $\begin{array}{l}3.90 \\
3.89\end{array}$ & $\begin{array}{l}.841 \\
.760\end{array}$ & 89 & -.073 & .942 \\
\hline & Superficial & $\begin{array}{c}\text { Gifted } \\
\text { Non-Gifted }\end{array}$ & $\begin{array}{l}2.88 \\
2.58\end{array}$ & $\begin{array}{l}.643 \\
.652\end{array}$ & 89 & -2.189 & $.031 *$ \\
\hline
\end{tabular}

$* \mathrm{p}<.05$

In Table 12, the results of the analysis of the father's educational status regarding the students 'preferences regarding mathematics learning approaches show that there is no significant difference between the mathematics learning approaches of the students in the two groups in high school graduate and lower graduates fathers' children. In the children of university graduate fathers, the scores in the depth and strategic learning approaches between the two groups did not differ significantly. On the other hand, the scores of gifted students were found to be significantly higher in the superficial learning approach compared to normal students $(\mathrm{t}=-2.18, \mathrm{p}<, 05)$.

The learning approaches of the students whose father's education level is "Post-graduate" were determined by Mann-Whitney U test since the group data did not show normal distribution and then presented in Table 13. In this category, there are $20(23.80 \%)$ fathers of gifted students and $8(5.17 \%)$ from the other group.

Table 13. Father's educational status Mann-Whitney U test results regarding mathematics learning approaches of students diagnosed with/without giftedness in the "Post-graduate" category

\begin{tabular}{|c|c|c|c|c|c|c|}
\hline Learning approaches & $\begin{array}{c}\text { Student } \\
\text { diagnosis }\end{array}$ & Rank average & Rank total & $\begin{array}{c}\text { M-Whitney } \\
U\end{array}$ & $Z$ & $p$ \\
\hline \multirow[t]{2}{*}{ In-Depth } & Gifted & 15,65 & 313,00 & 57,000 & $-1,174$ & 240 \\
\hline & Non-Gifted & 11,63 & 93,00 & & & \\
\hline \multirow[t]{2}{*}{ Strategic } & Gifted & 13,75 & 275,00 & 65,000 &,- 766 & ,444 \\
\hline & Non-Gifted & 16,38 & 131,00 & & & \\
\hline \multirow[t]{2}{*}{ Superficial } & Gifted & 16,15 & 323,00 & 47,000 & $-1,680$ & ,093 \\
\hline & Non-Gifted & 10,38 & 83,00 & & & \\
\hline
\end{tabular}


When the results of mathematics learning approaches of two groups of students according to father's education level are examined in Table 13, there is no significant difference in mathematics learning approaches of students whose father is at the graduate level.

\section{Discussion and Conclusion}

In this study, it has been tried to compare the mathematics learning approaches of students who are diagnosed as gifted and students not diagnosed as gifted. When the results are analyzed, it is determined that gifted students prefer in-depth and strategic learning approaches above the middle level and the superficial learning approach at the intermediate level. In parallel with this result, Renzulli, Rizza and Smith (2002) stated that gifted students have an in-depth learning approach. While students with no diagnosis of giftedness prefer the strategic and in-depth learning approach above the middle level, it is concluded that they prefer the superficial learning approach below the average score. The area in which students who adopt the in-depth learning approach with the increase in the level of success is frequently mentioned in the literature. For example, Bernardo (2003) stated that the frailty in success is related to superficial learning, but high success is related to in-depth and strategic learning approaches. The emergence of an in-depth and strategic learning approach above medium level in both students diagnosed as gifted and not diadnosed as gifted may have resulted from the high academic achievement of the participants. As Davis and Rimm (2004) stated, in order for the in-depth and strategic learning approach to be preferred more, positive environments where students can actively participate in learning processes, emphasize mathematical discussions and proofs through their own knowledge, explore through exploration mathematical concepts and representations, where they can switch these concepts should be created. Therefore, components such as teachers, books, tools in learning environments should be organized accordingly.

In student-centered learning environments instead of teacher-centered learning environments, it is also stated that students with superficial learning approach can change these approaches in the direction of learning in depth (Wilson \& Fowler, 2005). In order for students to prefer the in-depth learning approach more in mathematics lessons a student-centered problem-based learning environment (Gordon \& Debus, 2002; Sezgin-Selçuk, 2010), an inventive based teaching (Ünal \& Ergin, 2006) and an environment with computer-aided materials (Tinker, 1997) need to be created. Therefore, in a classroom where students with a superficial or strategic learning approach are abundant, the teacher can direct their students to in-depth learning with different activities according to the teaching method they choose (Göktepe-Yıldız \& Özdemir, 2018). As Biggs and Tang (2007) stated, by creating a better learning environment, more effective answers can be obtained from students, and teaching by presenting inquiry-based problems rather than teaching the information can encourage students to utilize in-depth learning approach. Similarly, Even, Karsenty and Friedlander (2009) also stated that the teacher, who has a very important role in mathematics and has a key role in creating opportunities for bright students to realize their own potential, will have various responsibilities in all these processes. In this study, as mentioned above, due to the fact that there are successful students in both groups, the in-depth learning approach may be overexposed. Therefore, the following suggestion can be given to the teacher, who is the lead responsible for organizing the learning environment, in order to have a positive change in the learning approach. Both students diagnosed with/without giftedness should be allowed to ask questions to their teachers, and great responsibilities fall towards the teachers to let them access information and encourage to thinking.

One of the remarkable results here is that the in-depth learning scores of gifted students are higher than the strategic learning scores; it is the result that students who are not diagnosed with giftedness have higher strategic learning scores than in-depth learning scores. The school chosen within the scope of the research was chosen from the school with the closest students to gifted students as an academic achievement. The preparations and exam successes of the students in this selected school are closely monitored by the school principal and school teachers, and a school atmosphere with an effort to improve the exam performance is provided. Therefore, it may be a consequence of this environment that students studying here prefer to do strategic learning more than indepth learning, which expresses their tendency to learn with exam success and grade anxiety.

There was a significant difference in favor of gifted students in the in-depth learning approach between gifted and normal students. However, no significant difference was found between the mean scores in strategic learning and superficial learning approaches. Similarly, Watkins (2001), Bernardo (2003) and Beyaztaş and Senemoğlu (2015) concluded that there is a positive relationship between academic achievement and in-depth learning so successful students use the in-depth learning approach more. In addition, Beyaztaş (2014) reached the conclusion that the scores of successful students who are in the first hundred in the $4^{\text {th }}$ grade of Science High School are high. As stated by Offir, Lev and Bezalel (2008), students who learn in depth associate the new information they have learned with their previous knowledge and make inferences from the information they have learned. Likewise, as Darlington (2011) puts it, it is important to understand where the knowledge is obtained considering the in-depth learning approach in mathematics subjects, knowing the usage areas of the subject, and establishing a relationship between them. It is stated in the literature that gifted individuals have the features such as easy and quick learning, loving to learn information in depth and details, showing high concentration and transferring 
what they have learned to other areas, wondering and analyzing cause and effect relationships, using their time and effort economically (Çitil \& Ataman, 2018). Considering these features, it is an expected result that gifted individuals do in-depth and strategic learning from time to time. Because, also in in-depth learning, the individual understands where the knowledge comes from, knows the usage areas, establishes the relationship between them, understands the subject, creates a harmonious whole from the related components, cares about the nature of the information and cares about cause and effect relationships (Byrne, Flood \& Willis, 2001; Darlington, 2011; Ramsden, 2000).

There is a meaningful difference in favor of female students in terms of in-depth and strategic learning subdimensions among gifted students. In other words, female students prefer more in-depth and strategic learning approaches than male students. No significant difference in the superficial learning approach by gender was found. In-depth and strategic learning approach is higher in girls with no gifted diagnoses than in boys, and lower in superficial learning approach. As a result of the analysis conducted to investigate whether these scores are statistically significant, it was determined that the scores differ significantly in the strategic learning approach. In line with the results of this research, Smith and Miller (2005) also concluded that male students showed a more superficial learning tendency compared to girls. Many reasons such as excessive self-confidence, fondness in game, computer games and activities, being more relax than girls, and perhaps even spending more time outside in this process may have been effective in the emergence of such a result in students with no gifted diagnosis. On the other hand, when we look at the studies conducted, the results of the study reversed, in other words, that the results for boys to prefer the deeper approach (Severiens \& ten Dam, 1997; Watkins, 1996) or that the female students preferred the deeper approach as is also seen in this study (Biggs, 2001). On the other hand, there are studies in which there is no significant difference between gender learning approaches as well (Öner, 2008; Richardson, 1993; Watkins \& Mboya, 1997; Tural-Dinçer \& Akdeniz, 2008).

Comparing the mathematics learning approaches of the students who were diagnosed with giftedness and not diagnosed as gifted according to the grade level, there was no significant difference in the mean scores at the $8^{\text {th }}$ grade level. However, it was observed that there was a significant difference in favor of gifted students in the indepth learning approach in the $7^{\text {th }}$ grade, and in superficial learning approach it was in favor of gifted students in the $6^{\text {th }}$ grade. In the $6^{\text {th }}$ grades, although the in-depth learning approach average scores are in favor of gifted students, this difference is not statistically significant. In their study Göktepe-Yıldız and Özdemir (2018), concluded that, as the grade level increases in students who are not diagnosed with giftedness, the tendency of the students to prefer the in-depth learning approach decreases and there is no difference in the students' preferring the superficial learning approach. The situation in this study may have been due to the ability of gifted students to ask more questions in their lessons and their will to reach the information themselves. On the other hand, in some studies with university students, this has been the opposite. (Ozan, Köse \& Gündoğdu, 2012; Senemoğlu, 2011). Another remarkable result here is a difference in favor of gifted students in superficial learning in $6^{\text {th }}$ grades. In the superficial learning approach, it is expected that gifted individuals will not perform superficial learning considering the fact that the information is memorized without the concern of seeking meaning and the information consists of torn pieces in the mind. Although the mean scores are below the medium level in both groups, this difference is thought to be due to constraints of the study group and may be specific to this group. In this study, the in-depth approach mean scores of gifted students decreased as the grade level increased, while the scores of normal students were ranked as $6^{\text {th }}, 8^{\text {th }}, 7^{\text {th }}$ grade from high to low. GöktepeY 1 ldız and Özdemir (2018) stated that, as the grade level increases, the learning environments in schools are expected to make more of the features of the in-depth learning approach work. Again, Göktepe-Y1ldiz and Özdemir (2018) stated that the decrease in the preference of learning in-depth may be related to the general exam held at the end of the 8th grade.

Beyaztaş and Senemoğlu (2015) came to the conclusion that approximately $40 \%$ of successful students' families have an impact on their children's adoption of in-depth learning approach due to changes such as setting goals, motivating, organizing and following their work. For this reason, in the research, some examinations were made for parents too as below. In the study, in comparison with the parents' professions between the two groups, there is a significant difference in favor of the gifted among the gifted and normal children whose parents work in the public sector in the in-depth learning approach. Another result is that, When the students' mathematics learning approaches according to the education level of the parents are examined, while no significant differentiation is observed between the two group of students whose mother graduated from high school and lower education levels, a significant differentiation was determined in favor of gifted students in the superficial learning approach between the students whose mother was university graduate. Comparing the children of mothers at post-graduate level, choosing the in-depth learning approach of gifted students has been statistically different in favor of gifted than the normal students. In the case of father education level, it is seen that there is a significant difference in favor of gifted students between the children of university graduates in two groups. It may be due to the mothers of post-graduate education level differentiate the preference of in-depth learning in their children, because as the mother's education level increases, she creates an appropriate learning-teaching environment that will indirectly enable her children to learn, thus motivating her children to learn. For this 
reason, in order to make the students become more in-depth learners, the efforts to improve the school-family cooperation can be improved so that the parents can take their own responsibility and parents can actively participate in the learning process.

Technology-supported learning environments can be created that will enable students to prefer in-depth learning approaches in mathematics lessons where students are more in center. Again, teachers can plan their lessons by asking problems that will make students think, so that students' learning approaches can be differentiated. In addition, the learning approaches of both groups can be examined in more depth and the underlying causes can be revealed. On the other hand, by encouraging teachers to make collaborative lessons, the richness of the prepared materials that play an active role in learning environments, the variety of asking questions, and the correct pedagogical approaches to their students can be improved. And this situation causes their students to adopt a deeper and more strategic learning style in their learning approach. 


\section{Üstün Yetenekli Öğrenciler ile Üstün Yetenekli Tanısı Konulmamış Öğrencilerin Matematik Öğrenme Yaklaşımlarının Karşılaştırılması}

\section{Giriş}

Öğrenmenin nasıl gerçekleştiği her zaman kafamızı meşgul etmiştir. Aslında bu durum beynin çalışma mekanizmasını tam olarak çözememiş olmamızdan kaynaklanmaktadır. Bireyin dış dünyadaki uyaranları algılaması ve algıladıklarını farklı şekillerde yorumlayıp kendine özgü bir ürüne dönüştürmesi bir öğrenme sürecidir (Beydoğan, 2007; Von Glasersfeld, 1996). Bu öğrenme sürecinde, bireylerin bireysel farklllıklar dikkate alındığında öğrenme yaklaşımlarının önemli bir yer tutabileceği söylenebilir. Marton ve Saljo (1976) tarafından ilk kez kullanılan öğrenme yaklaşımları kavramı, bireylerin bir okuma parçasını nasıl anladıklarının ortaya çıkarılmasında kullanılmıştır. Öğrenci ile öğrenme görevi arasındaki etkileşim olarak da tanımlanan (Ramsden, 2000) öğrenme yaklaşımı, bireyin bir konuyu öğrenirken gösterdiği eğilim olarak da ifade edilmektedir (Ekinci, 2009). Öğrenme yaklaşımı öğrencinin öğrenmedeki amacını, öğrenirken geçtiği süreci ve öğrenmeyi nasıl organize ettiğini ifade etmektedir (Spencer, 2003).

Öğrenmenin çok boyutlu bir kavram olması nedeniyle öğrenmeyi etkileyen yöntemlerin çok fazla ve çeşitli olabileceği düşünülebilir. Bireyin öğrenme yaklaşımlarının bilinmesi, öğretmenlerin öğretim durumlarını düzenlerken daha etkili ve yaratıc1 yollar bulmasına yardımcı olur (Biggs, 1999; Entwistle, 2000). Bu nedenle öğrencilerin öğrenmelerinin gerçekleşebilmesi için öğretim faaliyetlerinin gerçekleş̧irildiği ortamlarda öğrencilerin öğrenme yaklaşımlarının belirlenmesi gerekebilir. Bu sebepten dolayı Özgür ve Tosun (2012)'nun da belirttiği gibi öğrenme yaklaşımları, dikkate alınması ve araştırılması gereken bir konudur. Öğrenme yaklaşımları öğrencinin öğrenilen konuya yönelik tutumuna ve hazır bulunuşluk düzeyine, öğretmenin öğrenciye karşı tutumuna ve kullandığı öğretme yöntemlerine bağlıdır (Sezgin ve Ellez, 2002). Ayrıca öğrenme yaklaşımları; öğretim programının içeriği, işlevi, öğretim yöntem ve teknikleri, öğrenme ortamının özellikleri, değerlendirme yöntemleri gibi türlere göre de farklılaşmaktadır (Ekinci, 2009; Entwistle ve Smith, 2002).

Verimli ve etkili bir öğrenmenin gerçekleşmesinde öğrenme yaklaşımları önemlidir (Yıldız, 2015). Bu yüzden öğrencinin nasıl bir yaklaşımla öğrendiğini bilmek, onun nasıl bir öğrenci olduğunu anlayabilmek ve ona rehberlik edebilmek açısından önemlidir (Oğuz ve Karakuş, 2017). Aynı zamanda öğrenme yaklaşımlarının öğrenenin akademik başarısını etkilediği düşünüldüğünde (Öztaşkın, 2014) eğitim-öğretim sürecinde araştıran, sorgulayan başka bir ifadeyle öğrencileri yüzeysel ya da derin yaklaşımı kullanmaya iten faktörlerin belirlenmesi gerekmektedir (Çolak, 2006). Zaten matematik eğitimi üzerine yapılan araştırmalara bakıldığında, öğrencilerin matematik başarılarında etkili olan faktörlerin belirlenmesi üzerine yoğunlaşıldığı görülmektedir (Pourselami, Erfani ve Firoozfar, 2013; Zakaria ve Nordin, 2008). Bu faktörlerden birisinin de öğrencilerin matematik öğrenme yaklaşımlarının olduğu söylenebilir. Çünkü öğrencilerinin matematik öğrenme yaklaşımlarını bilen matematik öğretmenleri, kendi öğretim faaliyetlerini gözden geçirecekler ve öğrencilere doğru yönlendirmeler yaparak etkili bir öğretim gerçekleştirmek için çaba gösterebileceklerdir (Göktepe-Yıldız ve Özdemir, 2008).

Öğrenme yaklaşımını öğrencinin bilgiyi işleme biçimi olarak ele aldığımızda öğrencilerin öğrenmeyi ele alış biçimleri, yüzeysel öğrenme yaklaşımı, derinlemesine öğrenme yaklaşımı ve stratejik öğrenme yaklaşımı olarak üç grupta toplanabilir (Marton ve Saljo, 1976).

Derinlemesine öğrenme yaklaşımında; elde edinilen bilginin kaynağını anlamak, kullanım alanlarını bilmek ve aralarında ilişki kurmak esastır (Darlington, 2011). Derinlemesine öğrenme yaklaşımını tercih eden öğrencilerin esas amaçlarının anlama olduğu, ilgili bileşenlerin incelenmesinin öğrenmek için gerçekleştiği ve bu incelemenin uyumlu bir bütüne dönüştürülüp yapılandırıldığı bir süreçten geçtiği vurgulanmıştır (Chan, 2003; Ramsden, 2000). Byrne, Flood ve Willis (2009) da derinlemesine öğrenme yaklaşımına sahip olan bireylerin üst düzey öğrenme ürünleri elde edeceklerini ifade etmiştir. Curzon (2004) bu öğrenme yaklaşımıyla öğrencilerin, hipotezler oluşturarak test edebileceklerini ve konular arasındaki bağlantıları görmeye çalıştılarını vurgulamıştır.

Öğrenme yeteneğinin sabit, bilginin kesin ve değişmez olduğu inancının hâkim olduğu ve bilginin otorite tarafindan sunulduğu yaklaşım ise yüzeysel öğrenme yaklaşımı olarak adlandırılmaktadır (Chan, 2003). Biggs (2001) yüzeysel öğrenme yaklaşımını tercih eden öğrencilerin, üst düzey bilişsel becerileri kullanmayı gerektiren bir öğrenme etkinliğinde bile düşük düzeydeki becerileri kullandıklarını belirtmiştir. Yüzeysel öğrenme yaklaşımı ezberlenme odaklı olup, kavramlar arasında bir ilişki aranmaz (Biggs, 2001; Trigwell ve Prosser, 1991). Byrne, Flood ve Willis (2001) yüzeysel öğrenme yaklaşımına sahip olan öğrencilerin gerekli bilgiyi sınavlardan geçmek için ezberleme, bütünlük kurmadan ayrı ayrı parçalara odaklanma eğilimi içerisinde olma ve örnekleri kurallardan ayırt etmede başarısızlığın olduğunu belirtmişlerdir.

Başarılı olma niyeti ile öğrenme konusunu ele alan stratejik öğrenme yaklaşımındaki öğrenciler ise anlam arama ve oluşturma niyetinde değillerdir (Reid, Duvall ve Evans, 2007). Beydoğan (2007) bu öğrenme 
yaklaşımına sahip olan öğrencilerin olabildiğince yüksek notlar almaya çabalayacaklarını, çeşitli materyaller kullanılarak algılamalarını hızlandıracak kaynakları tercih edeceklerini bu şekilde de öğrenmelerinin kolaylaşacağını ifade etmiştir. Entwistle (1995) stratejik öğrenme yaklaşımının en önemli özelliğinin hem çalışma yöntemlerine hem de zaman yönetimi açısından organizasyona yarar sağladığını belirtmiş̧ir.

Öğrenme yaklaşımları üzerine yapılan çalışmalardan bazıları şu şekildedir. Beşoluk ve Önder (2010) yapmış olduğu çalışmasında lisans düzeyindeki öğretmen adaylarının daha çok yüzeysel öğrenme, yüksek lisans düzeyindeki öğretmen adaylarının ise daha çok derinlemesine öğrenme yaklaşımını tercih ettikleri sonucuna ulaşmışlardır. Değerlendirme yöntemlerinin öğrenme yaklaşımları üzerinde etkisinin araştırıldığı Scouller (1998)'in çalışmasında öğrencilerin çoktan seçmeli sınavlara hazırlanırlarken yüzeysel öğrenme yaklaşımını daha fazla tercih ettiği, üst düzey düşünme becerilerinin ölçüldüğü görevlerde ise öğrencilerin derinlemesine öğrenme yaklaşımını daha fazla tercih ettikleri sonucuna ulaşılmıştır. Yine Birenbaum ve Feldman (1998) derinlemesine öğrenme yaklaşımını benimseyen öğrencilerin düşünmeye sevk edici açık uçlu soruları daha fazla tercih ettiklerini belirlemiştir. Bir alana özgü olarak örneğin Lee, Johanson ve Tsai (2008) lise öğrencileri ile yapmış olduğu çalışmasında, fen öğrenme yaklaşımlarını incelemişler ve yapılandırmacı öğrenme anlayışlarına sahip öğrencilerin derinlemesine fen öğrenme yaklaşımlarına sahip olduklarını belirlemiş̧lerdir. Sezgin-Selçuk, Çalışkan ve Erol (2007), fizik öğretmen adaylarının öğrenme yaklaşımlarının belirlenmesi ve bu öğrenme yaklaşımlarının öğrencilerin cinsiyet, sınıf düzeyi, akademik başarıları gibi değişkenlerle incelenmesini amaçlamıştır. Sonuçta fizik öğretmen adaylarının derinlemesine öğrenme yaklaşımını, yüzeysel öğrenme yaklaşımına göre daha fazla tercih ettiklerini belirlemiştir. Özkan ve Sezgin-Selçuk (2014) lise öğrencilerinin fizik dersini öğrenirken benimsedikleri öğrenme yaklaşımlarını belirlemeyi amaçlamışlardır. Sonuçta fizik dersinde öğrencilerin derinlemesine ve yüzeysel öğrenme yaklaşımlarını orta düzeyin biraz üzerinde tercih ettikleri ve öğrenme yaklaşımlarının cinsiyetlerine göre anlamlı olarak farklılaşmadığı belirlenmiş̧ir. Alemdağ (2015) da beden eğitimi öğretmen adayları ile yapmış olduğu çalı̧̧masında bazı değişkenlere göre öğrenme yaklaşımlarını incelemiştir. Araştırmasının sonucunda derinlemesine öğrenme yaklaşımının benimsenmesinde sınıf düzeyi açısından anlamlı farklılıklar bulmuştur. Ayrıca akademik başarı ile öğrenme yaklaşımı arasında pozitif bir ilişki olduğunu belirlemiştir. Cano (2007) ise lise öğrencileriyle yapmış olduğu çalışmasında derinlemesine yaklaşım sergileyen öğrencilerin akademik başarılarının daha yüksek olduğu sonucuna ulaşmıştır. İlköğretim öğrencileri üzerine yapılan çalışmalara bakıldığında ise örneğin Çoban ve Ergin (2008) ilköğretim öğrencilerinin fen dersini öğrenme yaklaşımlarını belirlemeyi amaçlayan çalışmalarında; öğrencilerin derinlemesine ve yüzeysel öğrenme yaklaşımları puan ortalamalarının birbirine çok yakın olduğu ve cinsiyet açısından anlamlı olarak farklılaşmadığı saptanmıştır. Belge-Can ve Boz (2012) ilköğretim öğrencilerinin fen dersini öğrenirken tercih ettikleri öğrenme yaklaşımlarının cinsiyet ve yaş ile ilişkisini incelemişlerdir. Araştırmalarının sonucunda ise öğrencilerin yaşları arttıkça derinlemesine öğrenme yaklaşımını benimseme düzeylerinde azalma olduğu görülürken, tüm sinıf seviyelerinde ise daha çok derinlemesine öğrenme yaklaşımının benimsendiğini ortaya çıkmışır. Bununla birlikte kız öğrencilerin erkek öğrencilere göre derinlemesine öğrenme yaklaşımını daha çok tercih ettikleri tespit edilmiştir.

Matematik öğrenme yaklaşımlarının belirlenmesine yönelik olarak ise Chiu (2012), 5. sınıf öğrencileriyle yapmış olduğu araştırmada öğrencilerde matematik öğrenme anlayışını yapılandırmacı, yorumlayıcı, nesnelci, ulusun yerli halkın hak ve çıkarlarını koruyan ve yararcı olmak üzere 5 kategoride toplamıştır. Matic, Matic ve Katalenic (2013) mühendislik fakültesi öğrencilerinin matematik derslerinde sirasılyla stratejik, derinlemesine ve yüzeysel öğrenme yaklaşımlarını tercih ettiklerini belirlemişlerdir. Darlington (2011) da üniversite öğrencileriyle matematik öğrenme yaklaşımlarına yönelik yapmış olduğu araştırmasında öğrencilerin stratejik öğrenme yaklaşımını daha fazla benimsediğini tespit etmiştir. İlhan, Çetin ve Kılıç (2013) lise öğrencileriyle yapmış oldukları çalışmalarında matematik öğrenme yaklaşımları ölçeğini geliştirmeyi amaçlamışlar ve bu süreçte derin ve yüzeysel öğrenme yaklaşımı gibi iki faktör belirlenmiştir. Göktepe-Yıldız (2019) da yapmış olduğu çalışmasında tasarım temelli matematik uygulamalarının belirlenen boyutlarda 8. sınıf ögrencilerinin uzamsal yeteneklerine ve 3 boyutlu geometrik düşünme becerilerine etkisini incelemiştir. Ayrıca araştırmacı, matematik dersindeki öğrenme yaklaşımlarını ölçen ölçme aracı geliştirmiştir. Araştırma sonucunda öğrencilerin uzamsal yeteneklerinin matematik öğrenme yaklaşımlarına göre anlamlı farklılık gösterdiğini tespit etmiştir.

Çalışmalarda son yıllarda artış olmasına rağmen ülkemizde daha az çalışma olduğu görülmektedir (BelgeCan ve Boz, 2012; Beşoluk ve Önder, 2010; Çoban ve Ergin, 2008; Göktepe-Yıldız, 2019; İlhan ve ark., 2013; Sezgin-Selçuk ve ark., 2007). Diğer taraftan öğrenme yaklaşımlarının genel olarak incelenmesinin yerine bir alana özgü olarak incelenmesinin daha detaylı bilgiler verebileceği de ifade edilmektedir (Enwistle, 1997). Sonuçta İlhan ve arkadaşları (2013)'nın belirttiği gibi matematik öğrenme yaklaşımlarının diğer alanlardaki öğrenme yaklaşımlarından ayrılarak tek başına değerlendirilmesi daha uygun tespitlere yol açar. Oysa öğrenme yaklaşımları üzerine yukarıda da bahsedilen çalışmalara bakıldığında mevcut çalışmaların farklı öğrenim kademesine ve farklı derslere yönelik olduğu fakat matematik alanına özgü çalışmaların az olduğu (Chiu, 2012; Darlington, 2011; Göktepe-Yıldız, 2019; İlhan ve ark., 2013; Matic, Matic ve Katalenic, 2013) görülmektedir. Görüldüğü gibi matematik öğrenme yaklaşımları incelenmiş olsa dahi üstün yetenekli tanısı konulmuş 
öğrencilerle, üstün yetenekli tanısı konulmamış öğrencilerin matematik öğrenme yaklaşımlarının karşılaştırılması şeklindeki bir araştırmaya rastlanılmamıştır.

Okul programlarının üstün yetenekli tanısı konulmuş öğrencilerin eğitimsel ihtiyaçlarını karşılamadığını, programların çok yönlü ve yaratıcı özellikler taşıması gerektiği ifade edilmektedir (Baykoç, 2014; Kontaş, 2010; Palanc1, 2004). Üstün yetenekli tanısı konulmamış öğrencilerin üstün yetenekli öğrencilere göre matematiğin anlaşılmaz, soyut, zor ve karmaşık olabileceği yönünde düşünceleri daha fazla olabilir. Çünkü üstün yetenekli öğrenciler zor ve karmaşık olan yani zihinsel performans gerektiren uğraşlarda daha başarılıdırlar (Stuart ve Beste, 2011). Üstün yetenekli öğrencilerin sahip oldukları özellikler, bu öğrencilerin üstün yetenekli tanısı konulmamış öğrencilere göre daha başarılı ve daha hızlı öğrenmelerini sağlamaktadır (Ataman, 2004; Davis ve Rimm, 2004). Aslında bu tarz araştırmaların tespitleri ile öğrenme ortamları hazırlanırken gerekli düzenlemeler yapılarak dikkat edilmesi gereken hususlar belirlenebilir ve bu şekilde her iki grup için istenilen başarılar sağlanabilir. Bu doğrultuda bu iki grubun karşılaştırılmasının her iki grubun matematik öğretimi süreçleri için önemli sonuçlar ortaya koyabileceği söylenebilir. Zaten yapılan çalışmalara bakıldığında üstün yetenekli tanısı konulmuş ve konulmamış öğrencilerin çeşitli değişkenler yoluyla karşılaştırıldığ 1 da görülmektedir. Örneğin Mills (1993) yapmış olduğu çalışmasında matematik alanında üstün yetenekli öğrencilerin kişilik ve öğrenme stillerini araştırmış ve üstün yetenekli öğrenciler ile üstün yetenekli tanısı konulmayan öğrenciler arasında kişisel farklılar olduğunu belirlemiştir. Yıldız, Baltacı, Kurak ve Güven (2012) iki grubu problem çözme stratejilerini kullanma yönüyle karşılaştırmış ve üstün yetenekli öğrencilerin daha fazla strateji kullandıklarını ortaya koyarak üstün yetenekli tanısı konulmamış öğrencilerin eğitimine yön verecek önerilerde bulunmuşlardır. Altun ve Yazıcı (2010) araştırmalarında Dunn'un öğrenme stilleri envanterini kullanarak her iki grubun öğrenme stillerinde farklılıklar olduğunu ortaya koymuşlardır. Yine Arseven ve Yeşiltaş (2016) da iki grubun öğrenme stillerinin farklılaştığını üstün yetenekli öğrencilerin en çok "bağımsız" ve "rekabetçi”" öğrenme stillerini tercih ettiklerini, üstün yetenekli olmayan öğrencilerin ise en çok "bağımlı" ve "katılımcı" öğrenme stillerini tercih ettiklerini belirlemişlerdir. Yapılan bu çalışmada ise ortaokula devam eden her iki grup, matematik öğrenme yaklaşımları açısından karşılaştırılacaktır. Bir toplum nüfusunun çok az bir kesimini oluşturan bir kesiminin matematikteki öğrenme yaklaşımlarının belirlenmesiyle hem üstün yeteneklilerdeki mevcut durumun resmi çekilebilecek, hem de üstün yetenekli olmayan öğrenciler ile karşılaştırmalar yapılarak bu yönde de üstün yetenekliler ve üstün yetenekli tanısı konulmamış olmayan öğrencilerin eğitimlerinde bazı hamleler yapma firsat olabilecektir.

Üstün yeteneklilik kavramı; zekâ, liderlik kapasitesi veya özel akademik alanlarda yaşıtlarına göre yüksek düzeyde performans gösteren kişiler olarak tanımlanmaktadır (Horn, 2002; Ravenna, 2008; Renzulli, 1999). Bu nedenle geleceğin lider kadroları, bilim insanları ve sanatçılarının varlığı, üstün yeteneklilerin eğitimine verilen önemle doğru orantılıdır (Sisk, 1990). Bu yüzden üstün yetenekli bireylerin erken fark edilmeleri ve yeteneklerinin geliştirilmesi önemli iki husus olarak karşımıza çıkmaktadır (Çapan, 2010). Renzulli ve Reis (1985) üstün yetenekli çocukların normal programlar yoluyla sağlanamayan geniş kapsamlı eğitim olanaklarına ihtiyaç duyabileceklerini ifade etmişlerdir. Bu ihtiyacı karşılamak için ülkemizde ilk kez 1995'te açılan Bilim Sanat Merkezleri (BİLSEM) üstün yetenekli öğrencilerin; farklılıklarını önemseyen, öğrencilerin bilimsel düşünce ve davranışlara estetik ekleyen, üreten, sorun çözen ve kendini gerçekleştiren bireyler olmasını sağlamaya çalışmaktadır (Bilsem Yönergesi, 2007). Sowell, Zeigler, Bergwell ve Cartwright (1990) kendinden yaşça büyük öğrencilerin yapabildiği matematiksel becerileri sergileyebilen öğrencilere ise matematiksel alanda üstün yeteneklidir ifadesini kullanmışlardır. Holton ve Gaffney (1994) üstün yetenekli öğrencilerin matematik problemlerini çözerlerken analitik, tümdengelimli veya tümevarımlı düşünebildiklerini belirtmiştir. Üstün yetenekli öğrencilerin bu tür düşünme süreçlerinin ortaya çıkarılmasında onlara verilen matematik eğitiminin öneminin büyük olduğu aşikârdır. Ülkemizde de Bilim Sanat Merkezleri (BİLSEM) sayesinde üstün yetenekli öğrencilerin matematik eğitimine önem verildiği söylenebilir. Ülkemizde Bilim Sanat Merkezleri ile yapılan çalışmalar (Aktepe ve Aktepe, 2009; Baltacı, Yıldız ve Güven, 2014; Boran ve Aslaner, 2008; Yıldız, Baltacı, Kurak ve Güven, 2012; Aytekin, Baltacı, ve Yıldız, 2017) daha çok problem çözme, üstbiliş gibi farklı değişkenlere bağlı olarak yapılmıştır.

Yapılan bu çalışmada üstün yetenekli ve üstün yetenekli tanısı konulmamış öğrencilerin matematik öğrenme yaklaşımlarının incelenmesi ve ortaya çıkan durumların karşılaştırılması amaçlandığından araştırmanın ilgili bütün paydaşlara ve eğitim sistemimize yararlı bilgiler sağlayacağı düşünülmektedir. Yapılan bu çalışmada üstün yetenekli ve üstün yetenekli tanısı konulmamış başarılı öğrencilerin matematik öğrenme yaklaşımlarının üstün yeteneklilik tanısı, cinsiyet, sınıf düzeyi, velinin mesleği ve öğrenim durumu değişkenleri açısından incelenmesi amaçlanmıştır. Diğer taraftan araştırma sonunda elde edilen bulguların, matematik öğrenme yaklaşımlarına yönelik yapılmış çalışmalardaki sonuçlarla karşılaştırılması için firsat oluşacaktır. Bu nedenle araştırmanın problemi "Üstün yetenekli tanısı konulmuş ve konulmamış ancak başarılı öğrencilerin matematik öğrenme yaklaşımları bazı değişkenlere göre nasıl farklılık göstermektedir?” olarak belirlenmiştir. Çünkü öğrenme yaklaşımlarını öğrenenin yaşı, cinsiyeti, geçmiş yaşantılar, sınıf düzeyi, başarı düzeyi gibi birçok değişken etkilemektedir (Göktepe-Yıldız \& Özdemir, 2018; Senemoğlu, 2011; Trigwell ve Prosser, 1991). Bu nedenle araştırma problemi aşağıdaki değişkenlere göre de ayrıntılı incelenmiştir. 
Bu amaç kapsamında araştırmanın alt problemleri ise aşağıdaki gibidir;

1. Üstün yetenekli öğrenci tanısı konulmuş ve konulmamış öğrencilerin matematik öğrenme yaklaşımları nasildir?

2. Öğrenciler arasında üstün yetenek tanısına göre matematik öğrenme yaklaşımlarında istatistiksel bir fark var midır?

3. Cinsiyete göre üstün yetenekli tanısı konulmuş ve konulmamış öğrencilerin matematik öğrenme yaklaşımlarında istatistiksel olarak anlamlı farklılık bulunmakta mıdır?

4. Sınıf düzeylerine göre üstün yetenekli tanısı konulmuş ve konulmamış öğrencilerin matematik öğrenme yaklaşımlarında istatistiksel olarak anlamlı farklılık bulunmakta mıdır?

5. Velinin mesleğine göre üstün yetenekli tanısı konulmuş ve konulmamış öğrencilerin matematik öğrenme yaklaşımlarında istatistiksel olarak anlamlı farklılık bulunmakta mıdır?

Velinin öğrenim durumuna göre üstün yetenekli tanısı konulmuş ve konulmamış öğrencilerin matematik öğrenme yaklaşımlarında istatistiksel olarak anlamlı farklılık bulunmakta mıdır?

\section{Yöntem}

Bu bölümde; araştırmanın modeli, katılımcılar, verilerin toplanması, araştırmanın süreci ve analizi hakkında bilgiler verilmiştir.

\subsection{Araştırmanın Modeli}

$\mathrm{Bu}$ araştırmada üstün yetenekli öğrenciler ile üstün yetenekli tanısı konulmamış öğrencilerin matematik öğrenme yaklaşımları hakkında karşılaştırmalar yapılarak genel değerlendirmelere ulaşmak amaçlandığından betimsel araştırma modeli kullanılmıştır. Betimsel araştırmalar, var olan bir durumu herhangi bir deneysel işlem yapılmadan var olduğu şekliyle betimlemeyi amaçlamaktadır (Karasar, 2006). Yapılan bu araştırmada araştırma problemi cinsiyet, sınıf düzeyi, veli mesleği ve öğrenim durumu gibi değişkenler açısından da ayrı ayrı incelendiği için nedensel karşılaştırma yaklaşımı da kullanılmıştır. Cohen ve Manion (1994) nedensel karşılaştırma araştırmalarında aynı durumdan farklı şekillerde etkilenmiş en az iki grup ya da farz edilen durumdan etkilenmiş ve etkilenmemiş iki grubun olacağını ve mevcut durumun olası nedenlerini ve etkileyenlerini belirleyebilmek için bu grupların bazı değişkenler açışından incelenebileceğini belirtmiş̧lerdir. Var olan/ doğal olarak ortaya çıkmış bir durum ya da olayın nedenlerini ve bu nedenlere etki eden değişkenleri ya da bir etkinin sonuçlarını belirlemeye yönelik araştırmalar nedensel karşılaştırma araştırmalarıdır (Büyüköztürk, Çakmak, Akgün, Karadeniz ve Demirel, 2008).

\subsection{Katılımcilar}

Araştırmaya 2018-2019 eğitim öğretim yılında 6., 7. ve 8. sınıfa devam eden 84'ü üstün yetenekli öğrenci, 155 'i üstün yetenekli tanısı konulmamış öğrenci olmak üzere toplam 239 öğrenci katılmıştır. Üstün yetenekli öğrencilere ilişkin veriler İç Anadolu bölgesindeki bir ilin Bilim Sanat Merkezi'nden, üstün yetenekli tanısı konulmamış öğrencilere ilişkin veriler ise aynı ilde bulunan bir ortaokuldan toplanmıştır. Araştırmada akademik başarı açısından BİLSEM'deki öğrencilere en yakın okul seçilmeye dikkat edilmiştir. Akademik başarı olarak öğrencilerin birbirine yakın seçilmesinin nedeni, başarılı öğrenciler arasında üstün yetenek tanısının öğrenme yaklaşımları üzerinde bir farklılık oluşturup oluşturmayacağını incelemektir. Okul seçimi yapılırken liselere yerleştirme puan ortalamalarına göre araştırmanın yapıldığı ildeki bütün devlet okulları sıralanmış ve en başarılı olan okul seçilmiştir. Böylece devlet okulunun seçimi amaçlı örnekleme yöntemlerinden ölçüt örnekleme şeklinde olmuştur. Burada ölçüt olarak okul başarısı alınmıştır.

Tablo 1. Araştırmaya katılan öğrenci sayılarına ilişkin betimsel istatistikler

\begin{tabular}{|c|c|c|c|c|c|c|}
\hline \multirow{5}{*}{$\begin{array}{l}\text { Üstün yetenekli } \\
\text { öğrenciler }\end{array}$} & Sinıf düzeyi & \multirow{5}{*}{$\begin{array}{c}\mathrm{K} 1 \mathrm{z} \\
\text { Erkek }\end{array}$} & 6 & 7 & 8 & Toplam \\
\hline & \multirow[t]{2}{*}{ Cinsiyet } & & 23 & 15 & 9 & 47 \\
\hline & & & 15 & 9 & 13 & 37 \\
\hline & \multirow{2}{*}{$\begin{array}{c}\text { Toplam } \\
\text { f (\%) }\end{array}$} & & 38 & 24 & 22 & 84 \\
\hline & & & 45,24 & 28,57 & 26,19 & 100 \\
\hline \multirow{5}{*}{$\begin{array}{l}\text { Üstün yetenekli } \\
\text { tanısı konulmamış } \\
\text { öğrenciler }\end{array}$} & \multirow[t]{3}{*}{ Cinsiyet } & & 46 & 24 & 16 & 86 \\
\hline & & $\mathrm{K} 1 \mathrm{z}$ & & & & \\
\hline & & Erkek & 22 & 32 & 15 & 69 \\
\hline & \multirow{2}{*}{\multicolumn{2}{|c|}{$\begin{array}{c}\text { Toplam } \\
\mathrm{f}(\%)\end{array}$}} & 68 & 56 & 31 & 155 \\
\hline & & & 43,87 & 36,13 & 20 & 100 \\
\hline
\end{tabular}

Tablo 1'deki öğrencilerin cinsiyet, sınıf düzeyi ve üstün yetenek tanısına ilişsin demografik özelliklerinde görüldüğü gibi, araştırmaya 133 kız $(\% 55,6), 106(\% 44,4)$ erkek öğrenci katılmıştır. Üstün yetenekli tanısı konulmuş öğrencilerin 47'si $(\% 55,9)$ kız, 37'si $(\% 44,1)$ erkektir. Bu öğrencilerin sınıf düzeyine göre dağılımları 
ise; 6. sinıfta $38(\% 45,24)$ öğrenci, 7. sinıfta $24(\% 28,57)$ öğrenci ve 8 . sınıfta ise $22(\% 26,19)$ öğrenci şeklindedir. Üstün yetenekli tanısı konulmamış öğrencilerin \%55,4'ü kı, \%44,6'sının ise erkek olduğu anlaşılmaktadır. Sınıf düzeyine göre dağılımlara bakıldığında; 6 . sınıftan $68(\% 43,87), 7$. sınıftan $56(\% 36,13)$ ve 8. sınıfta ise $31(\% 20)$ öğrenci bulunmaktadır.

\subsection{Veri Toplama Araçları}

Matematik dersine özel olarak öğrenme yaklaşımlarını belirlemeye yönelik iki çalışma (Göktepe-Yıldız, 2019; İlhan ve ark., 2013) göze çarpmaktadır. Bu çalışmalardan İlhan ve arkadaşları (2013)'ın geliştirdikleri ölçek, yüzeysel ve derin öğrenme yaklaşımı şeklinde iki faktörlü bir yapıya sahiptir. Bu nedenle araştırmada Göktepe-Yıldız (2019)'ın ortaokul öğrencilerine uygun yüzeysel, derinlemesine ve stratejik öğrenme yaklaşımı şeklinde üç faktörü de ölçmeye yarayan ölçeği kullanılmıştır.

Göktepe-Yıldız (2019)'ın geliştirdiği Matematik Öğrenme Yaklaşımları Ölçeği; 33 maddeden ve derinlemesine öğrenme, yüzeysel öğrenme, stratejik öğrenme olmak üzere üç alt boyuttan oluşmaktadır. Ölçeğin alt boyutlarından alınan puanlar birbirinden bağımsız şekilde yorumlanmaktadır. Alt boyutlardan alınan yüksek puanlar öğrencilerin matematik dersinde o boyutu tercih etme eğilimlerinin yüksek olduğunu; düşük puanlar ise öğrencilerin matematik dersinde o boyutu tercih etme eğilimlerinin düşük olduğunu göstermektedir. Örneğin bir öğrencinin, “derinlemesine öğrenme yaklaşımı” yüksek olup, “stratejik öğrenme yaklaşımı” düşük olabilir.

Ölçek "Kesinlikle katılmıyorum=1" ile "Kesinlikle Katılıyorum=5" şeklinde 5'li likert tipinde bir ölçektir. Üç alt faktör tüm varyansın \%41.048'ini açıklamaktadır. Bu oran kabul edilebilir düzeydedir (Scherer vd,1988). Madde faktör yük değerleri. 323 ile. 713 arasında değişmektedir (Göktepe-Yıldız ve Özdemir, 2018). Bu çalışmanın analizlerine başlarken; ilk olarak hangi istatistiksel testlerin yapılacağına karar vermek için verilerin normal dağ 1 lım gösterip göstermediğine ilişkin çarpıklık (skewness) - basıklık (kurtosis) değerlerine bakılmıştır. Testin bütününe ait çarpıklık $(-, 886)$ ve basıklık $(1,414)$; derinlemesine alt boyutu için çarpıklık $(-, 959)$ ve basıklık (,293); stratejik alt boyutu için çarpıklık $(-1,085)$ ve basıklık $(, 847)$; yüzeysel alt boyutu için çarpıklık $(, 199)$ ve basıklık $(-, 512)$ şeklindedir.

Göktepe-Yıldız (2019) ölçeğin tümüne ait Cronbach alfa iç tutarlılık katsayısını .78 olarak belirlemiştir. Ardından derinlemesine öğrenme yaklaşımı alt boyutu için iç tutarlılık katsayısı .83, stratejik öğrenme yaklaşımı için .83, yüzeysel öğrenme yaklaşımı için .78 şeklinde tespitleri olmuştur. Bu çalışmada ise bu katsayılar tekrar hesaplanmış ve ölçeğin bütününe ait cronbach alfa güvenirlik katsayısı. 88 bulunmuştur. Alt boyutlarda bu sayı; derinlemesine öğrenme yaklaşımı için .89 , stratejik öğrenme yaklaşımı .90 yüzeysel öğrenme yaklaşımı için .77 olarak bulunmuştur. Genel olarak güvenirlik katsayısı. 70 ve üzerinde olan ölçekler, güvenilir kabul edildiğinden (Fraenkel, Wallend ve Hyun, 2012) bu ölçeğin yeterli derecede güvenilir olduğu söylenebilir.

\subsection{Verilerin Analizi}

Araştırmacılar, belirlenen BİLSEM ve il merkezinde yer alan ortaokula giderek kurum yöneticilerine araştırmayı anlatmışlar ve kurum yöneticilerinin de desteği ile ölçek formları öğrencilere uygulanmıştır. Öğrencilerden gelen ölçek formları sistematik olarak numaralandırılmış ve analiz yapılmak üzere muhafaza edilmiştir. Araştırmanın verileri, SPSS 23.00 paket programı kullanılarak analiz edilmiştir.

Çalışmanın analizlerine başlarken; matematik öğrenme yaklaşımlarının çeşitli değişkenlere göre farklılaşma durumunun belirlenmesi amacıyla gerçekleştirilecek istatistiksel analizlerin belirlenmesi için öncelikle bağımsız değişken düzeyinde bağımlı değişkenin normal dağılıp dağılmadığı incelenmiştir (Kolmogrow-Smirnow H testi). Üstün yetenek tan1s1 (K-S84=.075, p>.05; K-S155=.102, p>.05), cinsiyet (K-S133=.098, p>05; K-S106=.111, p. $>05)$, sinıf düzeyi (K-S106=.106, p >.05; K-S80=.140, p>.05; K-S53=.065, p>.05), anne mesleği $(\mathrm{K}-\mathrm{S} 73=.062$, p>.05; K-S29=.186, p<.05; K-S137=.114, p>.05) baba mesleği $(K-S 111=.059, p>.05 ; K-S 110=.150, p>.05 ; K-$ $\mathrm{S} 18=.115, \mathrm{p}<.05)$, anne öğrenim durumu (K-S139=.136, p>05; K-S76=.084, p>.05, K-S24=.128, p<.05), baba öğrenim durumu (K-S120=.120, p>.05; K-S91=.072, p>.05, K-S28=.087, p<.05) değişkenlerinin teste göre çıkan değerlerine uygun olarak dağılımları normal olan gruplar için bağımsız örneklemler t-testi, normal olmayanlar için Mann-Whitney U testi yapılmıştır. Verilerin analizi p<0.05 anlamlılık düzeyinde değerlendirilmiştir.

\section{Bulgular}

$\mathrm{Bu}$ bölümde üstün yetenekli öğrenciler ile üstün yetenekli tanısı koyulmayan öğrencilerin matematik öğrenme yaklaşımları; üstün yetenek tanısına, öğrencilerin sınıf düzeylerine, cinsiyetlerine, velilerin öğrenim durumlarına ve velilerin mesleğine göre ölçeğin geneli için raporlanmıştır.

\subsection{Birinci Alt Probleme İlişkin Bulgular}

Öğrencilerin matematik öğrenme yaklaşımlarına ilişkin betimsel istatistikler Tablo 2'de verilmiştir. 
Tablo 2. Matematik öğrenme yaklaşımlarına ilişkin betimsel istatistikler

\begin{tabular}{cccccc}
\hline Öğrenci Türü & Öğrenme yaklaşımı & Min & Maks & $\bar{X}$ & SS \\
\hline Üstün yetenekli & Derinlemesine & 21 & 55 & 44,50 & 8,96 \\
öğrenciler & Stratejik & 19 & 55 & 43,72 & 8,77 \\
& Yüzeysel & 18 & 55 & 33,30 & 8,38 \\
\hline Üstün yetenekli & Derinlemesine & 13 & 55 & 40,47 & 10,38 \\
tanısı konulmamış & Stratejik & 11 & 55 & 42,44 & 10,35 \\
öğrenciler & Yüzeysel & 13 & 55 & 31,54 & 9,13 \\
\hline
\end{tabular}

Tablo 2'de üstün yetenekli tanısı konulan ve konulmayan öğrencilerin matematik öğrenme yaklaşımlarına ilişskin betimsel istatistikler verilmiştir. Kullanılan ölçeğin her bir alt boyutunda 11 madde bulunduğundan, alt boyutlar için alınabilecek minimum puan 11, maksimum puan 55'dir. Buna bağlı olarak orta puan değeri de 33 olarak hesaplanmıştır. Öğrencilerin hangi öğrenme yaklaşımını tercih ettiğine ilişkin bulgularda üstün yetenekli bireyler için puan ortalamaları yüksekten düşüğe doğru derinlemesine öğrenme yaklaşımı, stratejik öğrenme yaklaşımı ve yüzeysel öğrenme yaklaşımı şeklinde sıralanmaktadır. Bu gruptaki öğrencilerin derinlemesine ve stratejik öğrenme yaklaşımı puan ortalamaları, orta puanın üzerindedir. Yüzeysel öğrenme yaklaşımı puan ortalaması ise yaklaşık olarak orta puan değerindedir. Bu bulgular doğrultusunda, üstün yetenekli öğrencilerin derinlemesine ve stratejik öğrenme yaklaşımlarını orta düzeyin üzerinde, yüzeysel öğrenme yaklaşımını ise orta düzeyde tercih ettikleri söylenebilir. Diğer taraftan üstün yetenekli tanısı konulmamış öğrencilerde puan ortalaması yüksekten düşüğe sırasıyla stratejik öğrenme yaklaşımı, derinlemesine öğrenme yaklaşımı ve yüzeysel öğrenme yaklaşımı şeklindedir. Tablo 2'de görüldüğü gibi üstün yetenekli tanısı konulmamış öğrenciler stratejik ve derinlemesine öğrenme yaklaşımını orta puanın üzerinde tercih ederken, yüzeysel öğrenme yaklaşımını orta puanın biraz altında tercih etmiştir.

\section{2. İkinci Alt Probleme İlişkin Bulgular}

Araştırmaya katılan 84 üstün yetenekli tanısı konulmuş, 155 üstün yetenekli tanısı konulmamış öğrencinin matematik öğrenme yaklaşımları arasında istatistiksel olarak anlamlı bir farklılaşma olup olmadığını incelemek için normallik testi yapılmış ve neticesinde normal dağılım gösterdiğinden t testi yapılmış Tablo 3 'te verilmiştir.

Tablo 3. Üstün yetenek tanısına göre matematik öğrenme yaklaşımlarına ilişkin bağımsız örneklemler t-testi sonuçları

\begin{tabular}{|c|c|c|c|c|c|c|}
\hline Öğrenme yaklaşımı & Öğrenci tanıs1 & $\bar{X}$ & $S S$ & $S D$ & $t$ & $p$ \\
\hline Derinlemesine & Üstün & 4,04 & ,94 & \multirow[b]{2}{*}{237} & \multirow[b]{2}{*}{$-2,99$} & \multirow[b]{2}{*}{$.003 *$} \\
\hline Oğrenme & Normal & 3,67 & ,81 & & & \\
\hline Stratejik Öğrenme & $\begin{array}{c}\text { Üstün } \\
\text { Normal }\end{array}$ & $\begin{array}{l}3,97 \\
3,85\end{array}$ & $\begin{array}{l}, 79 \\
, 94\end{array}$ & 237 &,- 962 & ,337 \\
\hline Yüzeysel Öğrenme & $\begin{array}{c}\text { Üstün } \\
\text { Normal }\end{array}$ & $\begin{array}{l}3,02 \\
2,86\end{array}$ & $\begin{array}{l}, 83 \\
, 76\end{array}$ & 237 & $-1,46$ &, 143 \\
\hline
\end{tabular}

$* \mathrm{p}<.05$

Öğrencilerin üstün yetenek tanısına göre matematik öğrenme yaklaşımlarının farklılaşıp farklılaşmadığını belirlemek için yapılan analiz sonucunda; üstün yetenekli ve normal öğrenciler arasında derinlemesine öğrenme yaklaşımında üstün yetenekliler lehine anlamlı bir farklılaşma gözlenmiştir $(\mathrm{t}=-2,99, \mathrm{p}<.05)$. Başka bir deyişle, üstün yetenekli öğrenciler matematik öğrenirken diğer öğrencilere göre daha fazla derinlemesine öğrenmeyi tercih etmektedir. Stratejik öğrenme $(\mathrm{t}=-, 96, \mathrm{p}>.05)$ ve yüzeysel öğrenme yaklaşımlarında $(\mathrm{t}=-1,46, \mathrm{p}>.05)$ puan ortalamaları arasında anlamlı fark bulunmamıştır.

\section{3. Üçüncü Alt Probleme İlişkin Bulgular}

Cinsiyete göre üstün yetenekli tanısı konulmuş ve konulmamış öğrencilerin matematik öğrenme yaklaşımlarındaki farklılığın tespiti için normallik testi sonucuna göre ise bağımsız örneklemler t-testi yapılmış ve sonuçlar Tablo 4'te sunulmuştur.

Tablo 4. Matematik öğrenme yaklaşımlarının cinsiyete göre t testi sonuçları

\begin{tabular}{|c|c|c|c|c|c|c|c|}
\hline & Öğrenme yaklaşımı & Cinsiyet & $\bar{X}$ & $S S$ & $S D$ & $t$ & $p$ \\
\hline \multirow{6}{*}{$\begin{array}{l}\text { Üstün yetenekli } \\
\text { öğrenciler }\end{array}$} & Derinlemesine & $\mathrm{K} 1 \mathrm{z}$ & 4,23 & ,704 & 82 & 2,40 & $.018^{*}$ \\
\hline & \multirow{3}{*}{ Stratejik } & Erkek & 3,81 & 891 & & & \\
\hline & & $\mathrm{K} 1 \mathrm{z}$ & 4,20 & 713 & 82 & 3,16 & $.002 *$ \\
\hline & & Erkek & 3,68 & 809 & & & \\
\hline & \multirow[t]{2}{*}{ Yüzeysel } & $\mathrm{K} 1 \mathrm{z}$ & 3,03 & ,762 & 82 & 01 & .991 \\
\hline & & Erkek & 3,02 &, 773 & & & \\
\hline
\end{tabular}


Tablo 4'ün devamı

\begin{tabular}{|c|c|c|c|c|c|c|c|}
\hline & Öğrenme yaklaşımı & Cinsiyet & $\bar{X}$ & $S S$ & $S D$ & $t$ & $p$ \\
\hline & Derinlemesine & $\mathrm{K} 1 \mathrm{z}$ & 3,77 & ,907 & 153 & 1,357 &, 177 \\
\hline Üstün yetenekli & & Erkek & 3,56 & ,982 & & & \\
\hline $\tan 1 \mathrm{~s} 1$ & Stratejik & $\mathrm{K} 1 \mathrm{z}$ & 4,00 & ,877 & 153 & 2,127 &, $035 *$ \\
\hline konulmamış & & Erkek & 3,68 & ,993 & & & \\
\hline öğrenciler & Yüzeysel & $\begin{array}{c}\text { K1z } \\
\text { Erkek }\end{array}$ & $\begin{array}{l}2,77 \\
2,98\end{array}$ & $\begin{array}{l}, 783 \\
, 877\end{array}$ & 153 & $-1,539$ &, 126 \\
\hline
\end{tabular}

$* \mathrm{p}<.05$

Kullanılan ölçeğin gereği olarak 3 alt boyut için de analiz yapılmıştır. Tablo 4’teki sonuçlar incelendiğinde, üstün yetenekli öğrenciler arasında; derinlemesine $(\mathrm{t}=2,40, \mathrm{p}<.05)$ ve stratejik öğrenme $(\mathrm{t}=3,16, \mathrm{p}<.05)$ alt boyutlarında cinsiyet değişkenine göre anlamlı bir farklılık görülmektedir. Görülen bu fark, kız öğrenciler lehinedir. Başka bir deyişle; üstün yetenekli kız öğrenciler erkek öğrencilere göre daha fazla derinlemesine ve stratejik öğrenme yaklaşımı tercih etmektedir. Yüzeysel öğrenme yaklaşımında ise cinsiyete göre anlamlı bir farklılık bulunmamaktadır $(\mathrm{t}=, 01, \mathrm{p}>.05)$. Üstün yetenekli tanısı konulmamış öğrencilerin analiz sonuçlarına bakıldığında kız öğrencilerin, derinlemesine ve stratejik öğrenme yaklaşımı puan ortalamaları erkeklere göre daha yüksek, yüzeysel öğrenme yaklaşımında daha düşük seviyededir. Öğrenciler arasında oluşan bu puan farkının istatiksel olarak anlamlı olup olmadığını araştırmak için yapılan analiz sonucunda yalnızca stratejik öğrenme yaklaşımında kız öğrencilerin puanlarının erkeklere göre anlamlı olarak daha yüksek olduğu belirlemiştir $(\mathrm{t}=2,12, \mathrm{p}<.05)$. Derinlemesine ve yüzeysel öğrenmede ise kız ve erkek öğrenciler arasındaki puan farkı anlamlı farklılaşma göstermemektedir.

\subsection{Dördüncü Alt Probleme İlișkin Bulgular}

Sınıf düzeylerine göre, üstün yetenekli tanısı konulmuş ve konulmamış öğrencilerin matematik öğrenme yaklaşımlarının değişip değişmediğinin analizi için normallik testi yapılmış ve neticesinde normal dağılım gösterdiğinden bağımsız örneklemler t testi ile analiz edilerek Tablo 5 'te sunulmuştur.

Tablo 5. Sınıf düzeylerine göre üstün yetenekli tanısı konulmuş/konulmamış öğrencilerin matematik öğrenme yaklaşımlarına ilişkin bağımsız örneklemler t-testi sonuçları

\begin{tabular}{|c|c|c|c|c|c|c|c|}
\hline Sınıf düzeyi & Öğrenme yaklaşımı & & $\bar{X}$ & $S S$ & $S D$ & $t$ & $p$ \\
\hline \multirow{6}{*}{6} & \multirow{2}{*}{ Derinlemesine } & Üstün & 4,18 & ,752 & \multirow{2}{*}{104} & \multirow{2}{*}{$-1,936$} & \multirow{2}{*}{,056 } \\
\hline & & Normal & 3,84 & ,915 & & & \\
\hline & \multirow{2}{*}{ Stratejik } & Üstün & 4,09 & ,799 & \multirow{2}{*}{104} & \multirow{2}{*}{,- 036} & \multirow{2}{*}{,972 } \\
\hline & & Normal & 4,08 &, 873 & & & \\
\hline & \multirow[b]{2}{*}{ Yüzeysel } & Üstün & 2,94 & ,726 & \multirow[b]{2}{*}{104} & \multirow[b]{2}{*}{$-2,218$} & \multirow[b]{2}{*}{,029* } \\
\hline & & Normal & 2,59 & ,785 & & & \\
\hline \multirow{6}{*}{7} & Derinlemesine & Üstün & 4,16 & 583 & \multirow{2}{*}{78} & \multirow{2}{*}{$-3,186$} & \multirow{2}{*}{, $000 *$} \\
\hline & \multirow{3}{*}{ Stratejik } & Normal & 3,45 & 1,01 & & & \\
\hline & & Üstün & 4,02 & ,781 & \multirow{2}{*}{78} & \multirow{2}{*}{$-1,842$} & \multirow{2}{*}{,069 } \\
\hline & & Normal & 3,59 & 1,02 & & & \\
\hline & \multirow[t]{2}{*}{ Yüzeysel } & Üstün & 3,25 &, 820 & \multirow{2}{*}{78} & \multirow{2}{*}{379} & \multirow{2}{*}{,706 } \\
\hline & & Normal & 3,32 & ,768 & & & \\
\hline \multirow{6}{*}{8} & Derinlemesine & Üstün & 3,67 & 1,02 & \multirow{2}{*}{51} & \multirow{2}{*}{,167 } & \multirow{2}{*}{,868 } \\
\hline & \multirow{3}{*}{ Stratejik } & Normal & 3,71 &, 800 & & & \\
\hline & & Üstün & 3,71 &, 785 & \multirow{2}{*}{51} & \multirow{2}{*}{, 524} & \multirow{2}{*}{,602 } \\
\hline & & Normal & 3,83 &, 822 & & & \\
\hline & \multirow[t]{2}{*}{ Yüzeysel } & Üstün & 2,92 & ,741 & \multirow{2}{*}{51} & \multirow{2}{*}{$-1,534$} & 131 \\
\hline & & Normal & 3,32 & ,681 & & & , \\
\hline
\end{tabular}

\section{$* \mathrm{p}<.05$}

Öğrencilerin sınıf düzeyine göre dağılımında 6. sınıfta 38 üstün yetenekli ile 68 normal öğrenci, 7. sınıfta 24 üstün ile 56 normal öğrenci, 8. sınıfta ise 22 üstün ile 31 normal öğrenci bulunmaktadır. Sınıf düzeyine göre üstün yetenekli tanısı konulmuş ve üstün yetenekli tanısı konulmamış öğrencilerin matematik öğrenme yaklaşımlarının karşılaştırılması amacıyla yapılan bağımsız örneklemler t-testi sonuçları incelendiğinde, 8.sınıf düzeyinde puan ortalamalarında anlamlı bir farklılaşma bulunmamıştır. Fakat 7. sınıfta derinlemesine öğrenmede üstün yetenekliler lehine $(\mathrm{t}=-3,18, \mathrm{p}<.05), 6$. sınıf düzeyinde ise yüzeysel öğrenme yaklaşımında üstün yetenekliler lehine $(\mathrm{t}=-2,21, \mathrm{p}<.05)$ anlamlı bir farklılaşma bulunduğu görülmektedir. 


\subsection{Beşinci Alt Probleme İlişsin Bulgular}

İki grup arasındaki matematik öğrenme yaklaşımları, velilerin mesleğine göre analiz edilmiş ve sonuçlar tablolaştırılarak aşăğıda sunulmuştur. Tablo 6 ve Tablo 7'de annelerin mesleğine göre; Tablo 8 ve Tablo 9'da babaların mesleğine göre üstün yetenekli tanısı konulmuş/konulmamış öğrencilerin matematik öğrenme yaklaşımları karşılaştırılmıştır. Grupların normal dağılım göstermesiyle anne mesleğine göre öğrencilerin matematik öğrenme yaklaşımlarının nasıl olduğu bağımsız örneklemler t testi ile analiz edilerek Tablo 6 'da sunulmuştur.

Tablo 6. Annenin mesleğine göre üstün yetenekli tanısı konulmuş/konulmamış öğrencilerin matematik öğrenme yaklaşımlarına ilişkin t testi sonuçları

\begin{tabular}{|c|c|c|c|c|c|c|c|}
\hline & Öğrenme Yaklaşımı & & $\bar{X}$ & $S S$ & $S D$ & $t$ & $p$ \\
\hline \multirow{5}{*}{ Kamu } & Derinlemesine & $\begin{array}{l}\text { Üstün } \\
\text { Normal }\end{array}$ & $\begin{array}{l}4,16 \\
3,62\end{array}$ & $\begin{array}{r}, 730 \\
749\end{array}$ & 71 & $-3,073$ &, $003 *$ \\
\hline & \multirow[t]{3}{*}{ Stratejik } & Üstün & 3,99 &, 869 & \multirow{3}{*}{71} & \multirow{3}{*}{-705 } & \multirow{3}{*}{,483 } \\
\hline & & Normal & 3,86 & 651 & & & \\
\hline & & Üstün & 3,08 & ,772 & & & \\
\hline & Yüzeysel & Normal & 2,77 &, 881 & 71 & $-1,575$ &, 120 \\
\hline \multirow{6}{*}{ Çalışmıyor } & Derinlemesine & Üstün & 3,91 & ,919 & \multirow{2}{*}{135} & \multirow{2}{*}{$-1,086$} & \multirow{2}{*}{, 280} \\
\hline & & Normal & 3,70 & ,980 & & & \\
\hline & \multirow[t]{2}{*}{ Stratejik } & Üstün & 3,93 & ,732 & \multirow{2}{*}{135} & \multirow{2}{*}{,- 401} & \multirow{2}{*}{,640 } \\
\hline & & Normal & 3,86 & 1,010 & & & \\
\hline & & Üstün & 2,93 &, 747 & \multirow{2}{*}{135} & \multirow{2}{*}{,060 } & \multirow{2}{*}{,952 } \\
\hline & Yüzeysel & Normal & 2,94 &, 811 & & & \\
\hline
\end{tabular}

$* \mathrm{p}<.05$

Üstün yetenekli öğrencilerin annelerinden kamuda çalışanların sayısı $43(\% 51,20)$, çalışmayanların sayısı ise $34(\% 40,47)^{\prime}$ tür. Üstün yetenek tanısı konulmamış öğrencilerin annelerinden kamuda çalışanların sayısı 30 $(\% 19,35)$, çalışmayanların sayısı ise $103(\% 66,46)$ 'tür. Tablo 6'da öğrencilerin anne mesleklerine göre öğrenme yaklaşımlarına bakıldığında, kamuda çalışan annelerin çocuklarında derinlemesine öğrenme yaklaşımı üstün yetenekli öğrenciler lehine istatistiksel olarak anlamlı bir şekilde farklılaşmaktadır $(\mathrm{t}=-3,07, \mathrm{p}<.05)$. Başka bir deyişle annesi kamuda çalş̧an üstün yetenekli bireyler normal öğrencilere göre daha fazla derinlemesine öğrenme yaklaşımını tercih etmektedir. Stratejik ve yüzeysel öğrenme yaklaşımlarında ise öğrenciler arasında herhangi bir anlamlı farklılaşmaya rastlanmamıştır.

Anneleri çalışmıyor kategorisinde olan öğrenciler için yapılan analizler sonucunda da görülüyor ki bu öğrenciler arasında hiçbir öğrenme yaklaşımında anlamlı bir farklılaşma görülmemiştir. Buna karşın üstün yetenekli öğrencilerin ortalamaları derinlemesine ve stratejik öğrenme yaklaşımında, diğer öğrenci grubuna göre fazladır.

Annesinin mesleği "Özel Sektör" olan öğrencilerin öğrenme yaklaşımları Mann-Whitney U testi ile belirlenmiştir. Çünkü üstün yetenekli öğrenci velilerinden $7(\% 8,33)$ anne ve diğer grubun velilerinden 22 $(\% 14,19)$ anne bu kategoride olup, veriler normal dağılmamıştır. Bu bağlamda ilgili sonuçlar, Tablo 7'deki şekildedir.

Tablo 7. Annesi "Özel Sektör" çalışanı olan üstün yetenekli tanısı konulmuş/konulmamış öğrencilerin matematik öğrenme yaklaşımlarına ilişkin Mann-Whitney U testi sonuçları

\begin{tabular}{clccccc}
\hline Öğrenme yaklaşımı & & $\begin{array}{c}\text { Stralar } \\
\text { ortalamast }\end{array}$ & $\begin{array}{c}\text { Siralar } \\
\text { toplamı }\end{array}$ & M-Whitney $U$ & $Z$ & $p$ \\
\hline \multirow{2}{*}{ Derinlemesine } & Üstün & 17,36 & 121,50 & 60,500 &,- 843 &, 399 \\
& Normal & 14,25 & 313,50 & & & \\
Stratejik & Üstün & 15,93 & 111,50 & 70,500 &,- 332 &, 740 \\
& Normal & 14,70 & 323,50 & & & \\
Yüzeysel & Üstün & 18,64 & 130,50 & 51,500 & $-1,302$ &, 193 \\
& Normal & 13,84 & 304,50 & & & \\
\hline
\end{tabular}

Tablo 7'de annesi özel sektör çalışanı olan öğrencilerin matematik öğrenme yaklaşımlarına ilişkin veriler sunulmuştur. Üstün yetenekli ve normal öğrencilerin matematik öğrenme yaklaşımlarında annesinin özel sektörde çalı̧̧ma durumuna göre gruplar arasında istatistiksel olarak herhangi bir farklılaşma oluşmadığı görülmüştür. 
Baba mesleğine ilişkin veriler ise aşağıdaki şekildedir.

Tablo 8. Babanın mesleğine göre üstün yetenekli tanısı konulmuş/konulmamış öğrencilerin matematik öğrenme yaklaşımlarına ilişkin t testi sonuçları

\begin{tabular}{|c|c|c|c|c|c|c|c|}
\hline & Öğrenme Yaklaşımı & & $\bar{X}$ & $S S$ & $S D$ & $t$ & $p$ \\
\hline \multirow{6}{*}{ Kamu } & Derinlemesine & Üstün & 4,04 & ,837 & \multirow{2}{*}{109} & \multirow{2}{*}{$-2,828$} & \multirow{2}{*}{, $006^{*}$} \\
\hline & \multirow{3}{*}{ Stratejik } & Normal & 3,59 & ,838 & & & \\
\hline & & Üstün & 4,01 & ,773 & \multirow{2}{*}{109} & \multirow{2}{*}{$-1,307$} & \multirow{2}{*}{,194 } \\
\hline & & Normal & 3,80 & ,895 & & & \\
\hline & \multirow[t]{2}{*}{ Yüzeysel } & Üstün & 2,92 & ,710 & \multirow{2}{*}{109} & \multirow{2}{*}{$-1,735$} & \multirow{2}{*}{,086 } \\
\hline & & Normal & 2,67 & ,778 & & & \\
\hline \multirow{6}{*}{ Özel sektör } & Derinlemesine & Üstün & 4,03 &, 828 & \multirow{2}{*}{108} & \multirow{2}{*}{$-1,484$} & \multirow{2}{*}{, 141} \\
\hline & & Normal & 3,71 & 1,037 & & & \\
\hline & Stratejik & Üstün & 3,96 &, 827 & \multirow{2}{*}{108} & \multirow{2}{*}{,- 418} & \multirow{2}{*}{,677 } \\
\hline & & Normal & 3,87 & 1,017 & & & \\
\hline & \multirow[t]{2}{*}{ Yüzeysel } & Üstün & 3,10 &, 785 & \multirow{2}{*}{108} & \multirow{2}{*}{,- 641} & \multirow{2}{*}{, 573} \\
\hline & & Normal & 2,99 &, 864 & & & \\
\hline
\end{tabular}

$* \mathrm{p}<.05$

Üstün yetenekli öğrencilerin babalarının kamuda çalışanlarının sayısı $51(\% 60,71)$ iken özel sektörde çalışanlarının sayısı $30(\% 35,72)$ 'dur. Üstün yetenekli tanısı konulmamış öğrencilerin babalarında ise bu durum kamuda çalışan $60(\% 38,71)$ ve özel sektörde $80(\% 51,61)$ şeklindedir. Tablo 8'de öğrencilerin baba mesleklerine göre öğrenme yaklaşımlarına bakıldığında, kamuda çalışan babaların çocuklarında derinlemesine öğrenme yaklaşımı, üstün yetenekli öğrenciler lehine istatistiksel olarak anlamlı bir şekilde farklılaşmaktadır $(\mathrm{t}=$ $-2,82, \mathrm{p}<.05)$.

Baba mesleği "Çalışmıyor” kategorisinde olan öğrencilerin öğrenme yaklaşımları da Mann-Whitney U testi ile belirlenmiştir. Üstün yetenekli öğrenci velilerinden $3(\% 3,57)$ baba ve diğer grubun velilerinden 15 baba $(9,68)$ bu kategoride olup, veriler normal dağılmamıştır. Bu bağlamda ilgili sonuçlar, Tablo 9'daki şekildedir.

Tablo 9. Babası "Çalışmıyor" kategorisindeki üstün yetenekli tanısı konulmuş/konulmamış öğrencilerin matematik öğrenme yaklaşımlarına ilişkin Mann-Whitney U testi sonuçları

\begin{tabular}{|c|c|c|c|c|c|c|}
\hline $\begin{array}{l}\text { Öğrenme } \\
\text { yaklaşımı }\end{array}$ & $\begin{array}{c}\text { Öğrenci } \\
\text { Tanısı }\end{array}$ & $\begin{array}{c}\text { Siralar } \\
\text { ortalamast }\end{array}$ & $\begin{array}{l}\text { Stralar } \\
\text { toplamı }\end{array}$ & $M$-Whitney $U$ & $Z$ & $p$ \\
\hline \multirow[t]{2}{*}{ Derinlemesine } & Üstün & 12,00 & 36,00 & 15,000 &,- 892 & ,373 \\
\hline & Normal & 9,00 & 135,00 & & & \\
\hline \multirow[t]{2}{*}{ Stratejik } & Üstün & 7,17 & 21,50 & 15,500 &,- 832 & ,405 \\
\hline & Normal & 9,97 & 149,50 & & & \\
\hline \multirow[t]{2}{*}{ Yüzeysel } & Üstün & 15,00 & 45,00 & 6,000 & $-1,958$ &, 050 \\
\hline & Normal & 8,40 & 126,00 & & & \\
\hline
\end{tabular}

$* \mathrm{p}<.05$

Tablo 9'da belirtildiği gibi babası bir işte çalışmayan öğrencilerin matematik öğrenme yaklaşımlarında herhangi anlamlı farklılaşma görülmemiştir.

İki grup arasında veli mesleklerine göre yapılan yukarıdaki 4 analizden görülüyor ki, derinlemesine öğrenme yaklaşımında kamuda çalışan anne ve babaların üstün ve normal çocukları arasında üstünler lehine anlamlı bir farklılaşma bulunmaktadır.

\subsection{Altıncı Alt Probleme İlişkin Bulgular}

Üstün yetenekli tanısı konulmuş öğrencilerin annelerinin öğrenim düzeylerindeki dağılıma bakıldığında, 24 kişi $(\% 28,57)$ lise mezunu ve altı, 40 kişi $(\% 47,62)$ ise üniversite mezunudur. Üstün yetenekli tanısı konulmamış öğrencilerin annelerin öğrenim düzeyleri ise; 115 kişi $(\% 74,19)$ lise ve altı mezunu, 36 kişi $(\% 23,22)$ üniversite mezunu şeklindedir.

Tablo 10 ve Tablo 11'de iki grup öğrencilerin velilerinden annelerin öğrenim durumları karşılaştırılarak sunulmuştur. 
Tablo 10. Annenin öğrenim durumuna göre üstün yetenekli tanısı konulmuş/konulmamış öğrencilerin matematik öğrenme yaklaşımlarına ilişkin bağımsız örneklemler t-testi sonuçları

\begin{tabular}{|c|c|c|c|c|c|c|c|}
\hline Öğrenim Durumu & Öğrenme Yaklaşımı & & $\bar{X}$ & $S S$ & $S D$ & $t$ & $p$ \\
\hline \multirow{6}{*}{ Lise mezunu ve alt 1} & Derinlemesine & Üstün & 3,87 & ,858 & \multirow{2}{*}{137} & \multirow{2}{*}{,- 876} & \multirow{2}{*}{,388 } \\
\hline & & Normal & 3,69 & ,958 & & & \\
\hline & Stratejik & Üstün & 3,81 &, 859 & \multirow{2}{*}{137} & \multirow{2}{*}{,277 } & \multirow{2}{*}{,782 } \\
\hline & & Normal & 3,87 & ,956 & & & \\
\hline & \multirow[t]{2}{*}{ Yüzeysel } & Üstün & 3,26 & ,697 & \multirow{2}{*}{137} & \multirow{2}{*}{$-1,426$} & \multirow{2}{*}{, 156} \\
\hline & & Normal & 3,00 & ,812 & & & \\
\hline \multirow{6}{*}{ Üniversite } & Derinlemesine & Üstün & 4,03 & ,876 & \multirow{2}{*}{74} & \multirow{2}{*}{$-1,630$} & \multirow{2}{*}{, 107 } \\
\hline & & Normal & 3,70 &, 870 & & & \\
\hline & Stratejik & Üstün & 4,01 & ,764 & \multirow{2}{*}{74} & \multirow{2}{*}{,- 668} & \multirow{2}{*}{,506 } \\
\hline & & Normal & 3,88 & ,896 & & & \\
\hline & \multirow[t]{2}{*}{ Yüzeysel } & Üstün & 2,78 &, 744 & \multirow{2}{*}{74} & \multirow{2}{*}{$-2,897$} & \multirow{2}{*}{, $005^{*}$} \\
\hline & & Normal & 2,31 & ,639 & & & \\
\hline
\end{tabular}

$* \mathrm{p}<.05$

Tablo 10 incelendiğinde annelerin öğrenim durumuna göre iki grup öğrencinin matematik öğrenme yaklaşımlarına yönelik sonuçlar incelendiğinde, annesi lise mezunu ve altı ögrenim düzeyinde olan iki grup arasında herhangi bir anlamlı farklılaşma gözlenmemiştir. Annesi üniversite mezunu olan öğrencilerin matematik öğrenme yaklaşımlarına bakıldığında; yüzeysel öğrenme yaklaşımında üstün yetenekli öğrencilerin puanları normal öğrencilere göre anlamlı olarak daha yüksektir $(\mathrm{t}=-2,89, \mathrm{p}<, 05)$. Derinlemesine ve stratejik öğrenme yaklaşımlarında ise puan ortalamaları üstün yetenekli öğrenciler lehine daha yüksek olsa da bu puan farkı istatistiksel olarak herhangi bir anlamlı fark oluşturmamaktadır.

Annesinin öğrenim durumu "Lisansüstü” olan öğrencilerin öğrenme yaklaşımları veriler normal dağılmadığ için Mann-Whitney U testi ile belirlenmiş ve Tablo 11'de sunulmuştur. $\mathrm{Bu}$ kategoride üstün yetenekli öğrencilerin annelerinden 20 kişi $(\% 23,81)$, diğer gruptan da 4 kişi $(\% 2,59)$ yer almaktadır.

Tablo 11. Annenin öğrenim durumu "lisansüstü” kategorisindeki üstün yetenekli tanısı konulmuş/konulmamış öğrencilerin matematik öğrenme yaklaşımlarına ilişkin Mann-Whitney U testi sonuçları

\begin{tabular}{ccccccc}
\hline \multirow{2}{*}{ Öğrenme yaklaşımı } & Öğrenci Tanısı & Stralar ortalaması & $\begin{array}{c}\text { Siralar } \\
\text { toplamı }\end{array}$ & M-Whitney $U$ & $Z$ & $p$ \\
\hline Derinlemesine & Üstün & 13,88 & 277,50 & 12,500 & $-2,140$ & $\mathbf{, 0 3 2}$ \\
& Normal & 5,63 & 22,50 & & \\
Stratejik & Üstün & 13,58 & 271,50 & 18,500 & $-1,669$ &, 095 \\
& Normal & 7,13 & 28,50 & & $-1,281$ &, 200 \\
Yüzeysel & Üstün & 11,68 & 233,50 & 23,500 & \\
& Normal & 16,63 & 66,50 & & & \\
\hline
\end{tabular}

$* \mathrm{p}<.05$

Tablo 11'den görüldüğü gibi lisansüstü öğrenim düzeyindeki annelerin ç̧ocukları karşılaştırıldığında ise, üstün yetenekli öğrencilerin derinlemesine öğrenme yaklaşım tercihi, normal öğrencilere göre istatistiksel olarak üstün yetenekliler lehine farklılaşmıştır $(\mathrm{z}=-2,14, \mathrm{p}<.05)$.

Babaların öğrenim durumlarına yönelik veriler ise aşağıda sunulmuştur. Üstün yetenekli tanısı konulmuş öğrencilerin babalarının öğrenim düzeylerindeki dağılımına bakıldığında, 18 kişi $(\% 21,44)$ lise ve altı mezunu iken 46 kişi $(\% 54,76)$ üniversite mezunudur. Üstün yetenekli tanısı konulmamış öğrencilerin babalarının öğrenim düzeyleri ise 102 kişi $(\% 65,80)$ lise ve altı mezunu, $45(\% 29,03)$ üniversite mezunu şeklindedir. Baba öğrenim durumu lise mezunu ve altı ile üniversite düzeyi olan verilerin analizinde grup verileri normal dağılım gösterdiği için bağımsız örneklemler t-testi uygulanmıştır (Tablo 12). 
Tablo 12. Babanın öğrenim durumuna göre üstün yetenekli tanısı konulmuş/konulmamış öğrencilerin matematik öğrenme yaklaşımlarına ilişkin bağımsız örneklemler t-testi sonuçları

\begin{tabular}{|c|c|c|c|c|c|c|c|}
\hline Öğrenim Durumu & $\begin{array}{l}\text { Öğrenme } \\
\text { Yaklaşımı }\end{array}$ & & $\bar{X}$ & $S S$ & $S D$ & $t$ & $p$ \\
\hline \multirow{6}{*}{ Lise mezunu ve altı } & Derinlemesine & Üstün & 3,94 & ,766 & \multirow{2}{*}{118} & \multirow{2}{*}{$-1,172$} & \multirow[b]{2}{*}{,243 } \\
\hline & & Normal & 3,65 & 1,012 & & & \\
\hline & Stratejik & Üstün & 4,077 &, 572 & \multirow{2}{*}{118} & \multirow{2}{*}{$-1,042$} & \multirow{2}{*}{, 135} \\
\hline & \multirow{3}{*}{ Yüzeysel } & Normal & 3,81 & 1,016 & & & \\
\hline & & Üstün & 3,12 & ,801 & \multirow{2}{*}{118} & \multirow{2}{*}{,- 502} & \multirow{2}{*}{, 617} \\
\hline & & Normal & 3,01 & 871 & & & \\
\hline \multirow{6}{*}{ Üniversite } & Derinlemesine & Üstün & 4,02 & ,842 & \multirow{2}{*}{89} & \multirow{2}{*}{$-1,764$} & \multirow[b]{2}{*}{,081 } \\
\hline & & Normal & 3,72 & ,792 & & & \\
\hline & Stratejik & Üstün & 3,90 & 841 & \multirow{2}{*}{89} & \multirow{2}{*}{,- 073} & \multirow{2}{*}{,942 } \\
\hline & & Normal & 3,89 & ,760 & & & \\
\hline & Yüzeysel & Üstün & 2,88 & ,643 & \multirow{2}{*}{89} & \multirow{2}{*}{$-2,189$} & \multirow{2}{*}{, $031 *$} \\
\hline & & Normal & 2,58 & ,652 & & & \\
\hline
\end{tabular}

$* \mathrm{p}<.05$

Tablo 12'de baba öğrenim durumunun öğrencilerin matematik öğrenme yaklaşımlarına ilişkin tercihlerine yönelik analiz sonuçlarında görülüyor ki, lise mezunu ve altı öğrenim düzeyindeki babaların çocuklarında iki gruptaki öğrencilerin matematik öğrenme yaklaşımları arasında anlamlı bir farklılaşma gözlenmemiştir. Üniversite mezunu babaların çocuklarında ise iki grup arasında derinlemesine ve stratejik öğrenme yaklaşımlarındaki puanlar anlamlı bir farklılaşma göstermemiştir. Buna karşın yüzeysel öğrenme yaklaşımında üstün yetenekli öğrencilerin puanları, normal öğrencilere göre anlamlı şekilde yüksek bulunmuştur $(\mathrm{t}=-2,18$, $\mathrm{p}<, 05)$.

Babasının öğrenim durumu "Lisansüstü” olan öğrencilerin öğrenme yaklaşımları grup verileri normal dağılım göstermediği için Mann-Whitney U testi ile belirlenmiş ve Tablo 13 'de sunulmuştur. Bu kategoride üstün yetenekli öğrencilerin babalarından 20 kişi $(\% 23,80)$, diğer gruptan da 8 kişi $(\% 5,17)$ yer almaktadır.

Tablo 13. Baba öğrenim durumu "Lisansüstü” kategorisindeki üstün yetenekli tanısı konulmuş/konulmamış öğrencilerin matematik öğrenme yaklaşımlarına ilişkin Mann-Whitney U testi sonuçları

\begin{tabular}{ccccccc}
\hline \multirow{2}{*}{ Öğrenme yaklaşımı } & Öğrenci & $\begin{array}{c}\text { Siralar } \\
\text { ortalamast }\end{array}$ & $\begin{array}{c}\text { Siralar } \\
\text { toplamı }\end{array}$ & M-Whitney $U$ & $Z$ & $p$ \\
\hline Tanısı & Üstün & 15,65 & 313,00 & 57,000 & $-1,174$ &, 240 \\
& Normal & 11,63 & 93,00 & & &, 444 \\
Stratejik & Üstün & 13,75 & 275,00 & 65,000 &,- 766 & \\
Yüzeysel & Normal & 16,38 & 131,00 & & &, 093 \\
& Üstün & 16,15 & 323,00 & 47,000 & $-1,680$ & \\
& Normal & 10,38 & 83,00 & & & \\
\hline
\end{tabular}

$* \mathrm{p}<.05$

Tablo 13’te baba öğrenim durumuna göre iki grup öğrencinin matematik öğrenme yaklaşımlarına yönelik sonuçlar incelendiğinde, babası lisansüstü öğrenim düzeyinde olan öğrencilerin matematik öğrenme yaklaşımlarında anlamlı bir farklılaşma gözlenmemiştir.

\section{Tartışma ve Sonuç}

$\mathrm{Bu}$ çalışmada üstün yetenekli ve üstün yetenekli tanısı konulmamış öğrencilerin matematik öğrenme yaklaşımları ortaya çıkarılarak karşılaştırılmaya çalışılmıştır. Sonuçlar incelendiğinde; üstün yetenekli öğrencilerin derinlemesine ve stratejik öğrenme yaklaşımlarını orta düzeyin üzerinde, yüzeysel öğrenme yaklaşımını ise orta düzeyde tercih ettikleri belirlenmiştir. Bu sonuçla paralel olarak Renzulli, Rizza ve Smith (2002) de üstün yetenekli öğrencilerin derinlemesine öğrenme yaklaşımına sahip olduklarını belirtmişlerdir. Üstün yetenekli tanısı konulmamış öğrenciler ise stratejik ve derinlemesine öğrenme yaklaşımını ortalama düzeyin üzerinde tercih ederken, yüzeysel öğrenme yaklaşımını orta puanın altında tercih ettiği sonucuna ulaşılmıştır. Başarı düzeyinin artmasıyla derinlemesine öğrenme yaklaşımını benimseyen öğrencilerin arttığı alan yazında sıkça belirtilmektedir. Örneğin Bernardo (2003), başarıdaki zayıflığın yüzeysel öğrenmeyle, lakin yüksek başarının derinlemesine ve stratejik öğrenme yaklaşımlarıyla ilişkili olduğunu belirtmiştir. Hem üstün yetenekli hem de üstün yetenekli tanısı konulmamış öğrencilerde derinlemesine ve stratejik öğrenme yaklaşımlarının orta düzeyin üzerinde çıkması şeklindeki bir sonucun ortaya çıkması, katılımcıların akademik başarılarının yüksek olmasından kaynaklanmış olabilir. Derinsel ve stratejik öğrenme yaklaşımının daha fazla tercih edilebilmesi için Davis ve Rimm (2004)'in ifade ettiği gibi öğrencilerin; öğrenme süreçlerine aktif olarak katılabilecekleri, kendi bilgileri aracılığıyla matematiksel tartışmalara ve ispatlara vurgu yapabilecekleri, 
keşfetme yoluyla araştırabilecekleri, matematiksel kavramlar ve bu kavramlara ait temsiller arasında geçiş yapabilecekleri pozitif ortamların oluşturulması gerekmektedir. O halde öğrenme ortamlarındaki öğretmen, kitap, araç gereç gibi bileşenler buna göre organize edilmelidir.

Öğretmen merkezli öğrenme ortamları yerine öğrenci merkezli öğrenme ortamlarında, yüzeysel öğrenme yaklaşımına sahip öğrencilerin, bu yaklaşımlarını derinlemesine öğrenme yönünde değiştirebilecekleri de belirtilmektedirler (Wilson ve Fowler, 2005). Öğrencilerin derinlemesine öğrenme yaklaşımını daha fazla tercih etmeleri için; matematik derslerinde öğrenci merkezli olan probleme dayalı öğrenme ortamının kullanıldığı (Gordon ve Debus, 2002; Sezgin-Selçuk, 2010) buluş yoluna dayalı öğretimin yapıldığı (Ünal ve Ergin, 2006) ve bilgisayar destekli materyallerin kullanıldığı (Tinker, 1997) ortamların oluşturulması gerekmektedir. Dolayısıyla yüzeysel ya da stratejik öğrenme yaklaşımına sahip öğrencilerin fazlaca olduğu bir sınıfta öğretmen, seçtiği öğretim yöntemine göre farklı etkinlikler ile öğrencilerini derinlemesine öğrenmeye yönlendirebilir (GöktepeYıldız ve Özdemir, 2018). Biggs ve Tang (2007)'ın da ifade ettiği gibi öğrenme ortamını daha iyi oluşturarak öğrencilerden daha etkili cevaplar alınabilir ve bilgileri açıklayarak öğretmekten ziyade sorgulama temelli problemler sunarak öğretim yapmak öğrencileri derinlemesine öğrenme yaklaşımını sergilemelerinde cesaretlendirebilir. Benzer şekilde Even, Karsenty ve Friedlander (2009) matematikte gelecek vadeden yani parlak öğrencilerin kendi potansiyellerini fark edebilmeleri için firsatlar yaratabilme anlamında oldukça kilit bir role sahip öğretmene, bütün bu süreçlerde çeşitli sorumlulukların düşeceğini belirtmiş̧tir. Bu araştırmada, yukarıda da bahsedildiği gibi her iki grupta da başarılı öğrenciler olması nedeni ile derinlemesine öğrenme yaklaşımı fazlaca sergilenmiş olabilir. Bu nedenle öğrenme ortamını düzenlemede birinci sorumlu olan öğretmene, öğrenme yaklaşımında pozitif bir değişikliğin olması için genel olarak şu öneri verilebilir. Hem üstün yetenekli hem de üstün yetenekli tanısı konulmamış öğrencilerin öğretmenlerine; soru sormaya izin vermeleri, bilgiye kendilerinin ulaşmaları ve düşünmeye sevk etmeleri yönünde büyük görevler düşmektedir.

Burada dikkat çeken sonuçlardan biri de öğrenme yaklaşımı puanlarına bakıldı̆̆ında üstün yetenekli öğrencilerin derinlemesine öğrenme puanlarının stratejik öğrenme puanlarından yüksek olduğu; üstün yetenek tanısı konulmayan öğrencilerin ise stratejik öğrenme puanlarının derinlemesine öğrenme puanlarından daha yüksek olduğu sonucudur. Araştırma kapsamında seçilen okul, akademik başarı olarak üstün yetenekli öğrencilere en yakın öğrencilerin okuldan seçilmiştir. Seçilen bu okuldaki öğrencilerin dönem içindeki sınavlara yaptıkları hazırlıklar ve sınav başarıları okul müdürü ve okul öğretmenleri tarafından yakından takip edilmekte ve sınav performansını yükseltme gayreti olan bir okul atmosferi sağlanmaktadır. Dolayısıyla burada öğrenim gören öğrencilerin sınav başarısı ve not kaygısı ile öğrenme eğilimini ifade eden stratejik öğrenmeyi, derinlemesine öğrenmeye göre daha fazla yapma tercihinde bulunması, bu ortamın bir neticesi olabilir.

Üstün yetenekli ve normal öğrenciler arasında derinlemesine öğrenme yaklaşımında üstün yetenekliler lehine anlamlı bir farklılaşma gözlenmiştir. Fakat stratejik öğrenme ve yüzeysel öğrenme yaklaşımlarında puan ortalamaları arasında anlamlı fark bulunamamıştır. Benzer şekilde Watkins (2001), Bernardo (2003) ve Beyaztaş ve Senemoğlu (2015) akademik başarı ile derinlemesine öğrenme arasında pozitif bir ilişki olduğu ve başarılı öğrencilerin derinlemesine öğrenme yaklaşımını daha fazla kullandıkları sonucuna ulaşmışlardır. Ayrıca Beyaztaş (2014) Fen lisesi 4. sınıfta ilk yüzde olan başarılı öğrencilerin derinlemesine öğrenme yaklaşımına ait puanlarının yüksek olduğu sonucuna ulaşmıştır. Offir, Lev ve Bezalel (2008)'in belirttiği gibi derinlemesine öğrenen öğrenciler; öğrendikleri yeni bilgileri daha önceki bilgileriyle ilişkilendirir, öğrendikleri bilgilerden çıkarımlarda bulunur. Yine Darlington (2011)'un ifade ettiği gibi derinlemesine öğrenme yaklaşımını matematik konuları içerisinde ele aldığımızda; elde edilen bilginin nereden geldiğini anlamak ve konunun kullanım alanlarını bilmek ve aralarında ilişki kurmak önemlidir. Üstün yetenekli bireylerin kolay ve çabuk öğrenme gerçekleştirmeleri, bilgiyi derinlemesine ve detaylarıyla öğrenmeyi sevmeleri, yüksek konsantrasyon gösterme ve hızlıca öğrendiklerini başka alanlara transfer edebilmeleri, neden sonuç ilişkilerini merak etme ve irdeleme, zamanlarını ve eforlarını ekonomik şekilde kullanma gibi özelliklere sahip olduğu literatürde ifade edilmektedir (Çitil ve Ataman, 2018). Bu özellikleri düşünüldüğünde üstün yetenekli bireylerin derinlemesine ve zaman zaman da stratejik öğrenme yapmaları beklenen bir sonuçtur. Zira derinlemesine öğrenmede de bireyde bilginin nereden geldiğini anlama, kullanım alanlarını bilme, aralarında ilişkiyi kurabilme, konuyu anlama-öğrenme için ilgili bileşenlerden uyumlu bir bütün oluşturma, bilginin doğasılyla ilgilenme ile neden sonuç ilişkileri önemseme (Byrne, Flood ve Willis, 2001; Darlington, 2011; Ramsden, 2000) söz konusudur.

Üstün yetenekli öğrenciler arasında derinlemesine ve stratejik öğrenme alt boyutlarında kız öğrenciler lehine anlamlı bir farklılık göstermektedir. Başka bir deyişle kız öğrenciler, erkek öğrencilere göre daha fazla derinlemesine ve stratejik öğrenme yaklaşımı tercih etmektedir. Yüzeysel öğrenme yaklaşımında ise cinsiyete göre anlamlı bir farklılık bulunmamıştır. Üstün yetenekli tanıs konulmamış kız öğrencilerde derinlemesine ve stratejik öğrenme yaklaşımı erkeklere göre daha yüksek, yüzeysel öğrenme yaklaşımında daha düşük seviyededir. Bu puanların istatiksel olarak anlamlı olup olmadığını araştırmak için yapılan analiz sonucunda stratejik öğrenme yaklaşımında puanların anlamlı şekilde farklılaştığı belirlenmiştir. Bu araştırma sonuçları ile paralel bir şekilde Smith ve Miller (2005) de yapmış oldukları çalışmalarında erkek öğrencilerin kızlara göre önemli ölçüde daha yüzeysel öğrenme eğilimi gösterdiği sonucuna ulaşmıştır. Üstün yetenekli tanısı konulmamış 
öğrencilerde bu şekilde bir sonucun ortaya çıkmasında aşırı özgüven, oyun, bilgisayar oyunlarına ve aktivitelerine düşkünlük, kızlara göre daha rahat davranış göstermeleri ve bu süreçte belki de dışarıda daha fazla zaman geçirmeleri gibi birçok neden olmuş olabilir. Diğer taraftan yapılan çalışmalara bakıldığında araştırmanın sonuçlarının tam tersine yani erkeklerin derinlemesine yaklaşımı daha fazla tercih etmesine yönelik sonuçların ortaya çıktığı (Severiens ve ten Dam, 1997; Watkins, 1996) ya da bu çalışmadaki gibi kız öğrencilerin derinlemesine yaklaşımı daha çok tercih ettikleri (Biggs, 2001) de görülmektedir. Diğer taraftan cinsiyete göre öğrenme yaklaşımları arasında anlamlı bir farklılığın olmadığı çalışmalar (Öner, 2008; Richardson, 1993; Watkins ve Mboya, 1997; Tural-Dinçer ve Akdeniz, 2008) da vardır.

Sınıf düzeyine göre üstün yetenekli tanısı konulmuş ve üstün yetenekli tanısı konulmamış öğrencilerin matematik öğrenme yaklaşımları karşılaştırıldığında 8.sınıf düzeyinde puan ortalamalarında anlamlı bir farklılaşma bulunmamıştır. Fakat 7. sınıfta derinlemesine öğrenme yaklaşımında üstün yetenekliler lehine, 6 . sınıf düzeyinde ise yüzeysel öğrenme yaklaşımında üstün yetenekliler lehine anlamlı bir farklılaşma bulunduğu görülmüştür. 6. sınıflarda, yine derinlemesine öğrenme yaklaşımı puan ortalamaları üstün yetenekli öğrenciler lehine olsa da bu puan farkı istatistiksel olarak anlamlı değildir. Göktepe-Yıldız ve Özdemir (2018) araştırmasında, üstün yetenekli tanısı konulmamış öğrencilerde sınıf düzeyi yükseldikçe öğrencilerin derinlemesine öğrenme yaklaşımını tercih etme eğilimlerinin azaldığı ve öğrencilerin yüzeysel öğrenme yaklaşımını tercih etme durumlarında ise bir farklılığın olmadığı sonuçlarına ulaşmıştır. Bu araştırmadaki durum da üstün yetenekli öğrencilerin derslerinde daha fazla sorular sormaları ve bilgiye kendilerinin ulaşma istekleri nedeniyle olmuş olabilir. Diğer taraftan üniversite öğrencileriyle yapılan bazı çalışmalarda, bu durum tam tersine gerçekleşmiştir (Ozan, Köse ve Gündoğdu, 2012; Senemoğlu, 2011). Burada dikkat çeken bir diğer sonuç; 6 . sınıflarda yüzeysel öğrenmede üstün yetenekli öğrenciler lehine bir farklılık bulunmuştur. Yüzeysel öğrenme yaklaşımında anlam arama kaygısı güdülmeksizin bilginin ezberlenmesi ve bilginin zihinde kopuk parçalardan oluşması durumu düşünüldüğünde üstün yetenekli bireylerin yüzeysel öğrenme yapmaması beklenmektedir. Puan ortalamaları her iki grupta da orta düzeyin altında olmakla beraber, oluşan bu farkın çalışma grubunun sınırlılığ1 ve bu gruba özgü olabileceği düşünülmektedir. Bu çalışmada üstün yetenekli öğrencilerin derinlemesine yaklaşım puan ortalamaları sınıf düzeyi yükseldikçe düşmüş, normal öğrencilerin ise puanları yüksekten düşüğe 6.-8.-7. sınıf şeklinde sıralanmıştır. Göktepe-Yıldız ve Özdemir (2018) sınıf düzeyi yükseldikçe okullardaki öğrenme ortamlarının derinlemesine öğrenme yaklaşımının özelliklerini daha çok işe koşmasının beklendiğini ifade etmişlerdir. Yine Göktepe-Yıldız ve Özdemir (2018) derinlemesine öğrenme yapma tercihinin azalmasının öğrencilerin 8. sınıf sonunda yapılan sınavla ilgili olabileceğini belirtmiştir.

Beyaztaş ve Senemoğlu (2015) başarılı öğrencilerin yaklaşık \% 40’ının ailelerinin hedef koyma, motive etme, çalışmalarını organize etme ve takip etme gibi değişenler nedeni ile çocuklarının derinlemesine öğrenme yaklaşımını benimsemelerinde bir etkisinin olduğu sonucuna ulaşmışlardır. Bu nedenle araştırmada, aşağıdaki gibi velilere yönelik bazı incelemeler de yapılmıştır. Araştırmada iki grup arasında veli mesleklerine göre yapılan karşılaştırmada derinlemesine öğrenme yaklaşımında kamuda çalışan anne ve babaların üstün ve normal çocukları arasında üstünler lehine anlamlı bir farklılaşma bulunmaktadır. Başka bir sonuçta ise; velilerin öğrenim durumuna göre öğrencilerin matematik öğrenme yaklaşımları incelendiğinde, anne öğrenim durumunda, annesi lise ve altı öğrenim düzeyinden mezun öğrenciler arasında herhangi bir anlamlı farklılaşma gözlenmezken; annesi üniversite mezunu olan öğrencilerden iki grup arasında yüzeysel öğrenme yaklaşımında üstün yetenekli öğrenciler lehine anlamlı bir farklılaşma belirlenmiştir. Lisansüstü öğrenim düzeyindeki annelerin çocukları karşılaştırıldığında ise, üstün yetenekli öğrencilerin derinlemesine öğrenme yaklaşımı tercihi normal öğrencilere göre istatistiksel olarak üstün yetenekliler lehine farklılaşmıştır. Baba öğrenim durumunda ise üniversite mezunu babaların iki gruptaki çocukları arasında yüzeysel öğrenmede üstün yetenekliler lehine anlamlı bir farklılaşma olduğu görülmektedir. Lisansüstü öğrenim düzeyindeki annelerin çocuklarında derinlemesine öğrenme tercihinin anlamlı şekilde farklılaşması, annenin eğitim düzeyinin artmasıyla beraber çocuklarının da öğrenme yapmasına imkân verecek uygun öğrenme-öğretme ortamı hazırlaması, dolayısıyla çocuklarını dolaylı yoldan derinlemesine öğrenme yapması için motive etmesi nedeniyle olabilir. Bu yüzden öğrencilerin daha çok derinlemesine öğrenenler haline getirilmesinde ailenin de kendi sorumluluğunu alabilmesi için okul-aile iş birliğinin geliştirilmesine yönelik çalışmalar iyileştirilerek velilerin öğrenme sürecine aktif olarak katılmaları sağlanabilir.

Öğrencilerin matematik derslerinde derinlemesine öğrenme yaklaşımlarını tercih etmelerini sağlayacağımız öğrencilerin daha çok merkezde olduğu teknoloji destekli öğrenme ortamları oluşturulabilir. Yine öğretmenler öğrencileri düşünmeye sevk edecek problemler sorarak derslerini planlayabilirler bu şekilde öğrencilerin öğrenme yaklaşımları farklılaştırılabilir. Ayrıca her iki grubun öğrenme yaklaşımları daha derinlemesine incelenip altında yatan sebepler de ortaya çıkarılabilir. Diğer taraftan öğretmenlerin ders imecesi yapmaları teşvik edilerek öğrenme ortamlarında etkin rol oynayan hazırlanan materyallerin zenginliği, soru sorma çeşitliliği ve öğrencilerine doğru pedagojik yaklaşımlarda bulunma geliştirilebilir. Bu durum da öğrencilerinin öğrenme yaklaşımlarında daha çok derinsel ve stratejik öğrenme şeklini benimsemelerine yol açar. 


\section{Kaynaklar / References}

Aktepe, V., \& Aktepe, L. (2009). Teaching method using science and technology education on students' aspects: The example of Kırsehir CAS. Ahi Evran University Journal of Kırşehir Education Faculty (JKEF), 10(1), 69-80.

Alemdağ, C. (2015). Beden ĕgitimi öğretmeni adaylarının epistemolojik inançları, akademik öz-yeterlikleri ve ögrenme yaklaşımları (Yayımlanmamış Doktora Tezi), Karadeniz Teknik Üniversitesi, Eğitim Bilimleri Enstitüsü, Trabzon.

Altun, F., \& Yazıc1, H. (2010). Learning styles of the gifted students in Turkey. Procedia Social and Behavioral Sciences, 9, 198-202.

Arseven, A. ve Yeşiltaş, E. (2016). Üstün yetenekli öğrencilerin ve üstün yetenekli olmayan akranlarının öğrenme stillerinin karşılaştırılması. Turkish Studies, 11(2), 67-84.

Ataman, A. (2004). Üstün zekâlı ve üstün özel yetenekli çocuklar. Şirin, M. R., Kulaksızoğlu A. ve Bilgili A. E. (Eds.), Üstün yetenekli çocuklar seçilmiş makaleler kitabı içinde (ss. 155- 168). İstanbul: Çocuk Vakfı Yayınlar1.

Aytekin, C., Baltaci, S., \& Yildiz, A. (2017, Mayıs). Probability explorer simülasyonunun üstün zekâll/yetenekli ögrencilere olasılıkögretmedeki kullanışlılığına ilişkin bilsem matematik öğretmenlerinin görüşleri. International Talented and Gifted Conference: New Approaches and Educational Practices Sempozyumu'nda sunulan bildiri. Ankara, Turkey.

Baltaci, S., Yıldız, A., \& Güven, B. (2014). Knowledge types used by eighth grade gifted students while solving problems. Mathematics Education Bulletin, 28(50), 1032-1056.

Baykoç, N. (2014). Üstün; akıl, zekâ, deha, yetenek, dahiler-savantlar gelişimleri ve eğitimleri. Ankara: Vize Yayıncilik.

Belge-Can, H. ve Boz, Y. (2012, Haziran). Yaş ve cinsiyetin ilköğretim öğrencilerinin fen dersini öğrenme yaklaşımlarına etkisi. X. Ulusal Fen Bilimleri ve Matematik Eğitimi Kongresi’nde sunulan bildiri. Niğde.

Bernardo, A. B. I. (2003). Approaches to learning and academic achievement of Filipino students. Journal of Genetic Psychology, 164, 101-114.

Beşoluk, Ş. ve Önder, İ. (2010). Öğretmen adaylarının öğrenme yaklaşımları, öğrenme stilleri ve eleştirel düşünme eğilimlerinin incelenmesi. Illkögretim Online, 9(2), 679-693.

Beyaztaş, İ. D. (2014). Başarılı ögrencilerin öğrenme yaklaşımları ve etkili ögrenmeye ilişkin önerileri (Yayımlanmamış Doktora Tezi). Hacettepe Üniversitesi, Eğitim Bilimleri Enstitüsü, Ankara.

Beyaztaş, İ. D. ve Senemoğlu, N. (2015). Başarılı öğrencilerin öğrenme yaklaşımları ve öğrenme yaklaşımlarını etkileyen faktörler. Eğitim ve Bilim, 40(179), 193-216.

Beydoğan, Ö. (2007). Derinliğine ve yüzeysel öğrenmede kavram haritaları ve şemaların işlevi. Milli Eğitim, $173,258-270$.

Biggs, J. (1999). What the student does: Teaching for enhanced learning. Higher Education Research \& Development, 18(1), 57-75.

Biggs, J. (2001). Enhancing learning: a matter of style or approach? In R. J. Sternberg, \& L. F. Zhang (Eds.), Perspective on thinking, learning, and cognitive styles (pp. 73-102). London: Lawrence Erlbaum Associates, Inc.

Biggs, J., \& Tang, C. (2007). The society for research into higher education teaching for quality learning at university. USA: McGraw Hill.

Birenbaum, M., \& Feldman, R. A. (1998). Relationships between learning patterns and attitudes towards two assessment formats. Educational Research, 40(1), 90-98.

Boran, A.İ., \& Aslaner, R. (2008). Problem-based learning in teaching mathematics at the science-art centers. Inönü University Journal of the Faculty of Education, 9(15), 15-32.

Büyüköztürk, Ş., Çakmak, E., Akgün, Ö., Karadeniz, Ş. ve Demirel, F. (2008). Bilimsel araştırma yöntemleri. (1. Baskl). Ankara: Pegem Akademi.

Byrne, M., Flood, B., \& Willis, P. (2001). The relationship between learning approaches and learning outcomes: A study of Irish accounting students. Accounting Education, 11, 1, 27-42.

Byrne, M., Flood, B., \& Willis. P. (2009). An inter-institutional exploration of the learning approaches of students studying accounting. International Journal of Teaching and Learning in Higher Education, 20(2), $155-167$

Cano, F. (2007). Approaches to learning and study orchestrations in high school students. European Journal of Psychology Education, 2, 131- 151.

Chan, K. (2003). Hong Kong teacher education students' epistemological beliefs and approaches to learning. Research in Education, 69, 36-50.

Chiu, M. S. (2012). Identification and assessment of taiwanese children's conceptions of learning mathematics. International Journal of Science and Mathematics Education, 10, 163-191.

Cohen, L., \& Manion, L. (1994). Research methods in education. London, Routeledge.

Curzon, L. B. (2004). Teaching in further education an outline of principles and practise. New York: Continuum. 
Çapan, E. B. (2010). Öğretmen adaylarının üstün yetenekli öğrencilere ilişkin metaforik algıları. The Journal of International Social Research, 3(12), 140-154.

Çitil, M. ve Ataman, A. (2018). İlköğretim çağındaki üstün yetenekli öğrencilerin davranışsal özelliklerinin eğitim ortamlarına yansıması ve ortaya çıkabilecek sorunlar. Gazi University Journal of Gazi Educational Faculty (GUJGEF), 38(1),185-231.

Çoban, G. Ü., ve Ergin, Ö. (2008). İlköğretim öğrencilerinin feni öğrenme yaklaşımları. Uludă̆ Üniversitesi Ĕgitim Fakültesi Dergisi, 21(2), 271-293.

Çolak, E. (2006). İşbirliğine dayalı öğretim tasarımının öğrencilerin öğrenme yaklaşımlarına, akademik başarılarına ve öğrenmenin kalıcılığına etkisi (Yayımlanmamış doktora tezi). Yıldız Teknik Üniversitesi, Sosyal Bilimler Enstitüsü, İstanbul.

Darlington, E. (2011). Approaches to learning of undergraduate mathematicians. In Smith, C. (Ed.) Proceedings of the British Society for Research into Learning Mathematics (BSRLM), (Vol.31,pp.41-46). Oxford, England.

Davis, G. A., \& Rimm, S. B. (2004). Education of the gifted and talented. Boston, MA: Pearson Education Press.

Ekinci, N. (2009). Üniversite öğrencilerinin öğrenme yaklaşımları. Eğitim ve Bilim, 34(151), 74-88.

Entwistle, N. J. (1995). Frameworks for understanding as experienced in essay writing and in preparing for examinations. Educational Psychologist, 30(1), 47-54.

Entwistle, N. (2000, June). Promoting deep learning through teaching and assessment. Paper presented at the AAHE Assessment Conference, North Carolina.

Entwistle, N.J., \& Smith, C.A. (2002). Personal understanding and target understanding: Mapping influences on the outcomes of learning. British Journal of Educational Psychology, 72, 321-342.

Even, R., Karsenty, R., \& Friedlander, A. (2009). Mathematical creativity and giftedness in teacher professional development. In R. Leikin, A. Berman \& B. Koichu (Eds.), Creativity in Mathematics and the Education of Gifted Students (pp. 309-324). Rotterdam, The Netherlands: Sense Publishers.

Fraenkel, J. R., Wallend, N.E., \& Hyun, H. H. (2012). How to design and evaluate research in education. New York: McGraw Hill.

Gordon, C., \& Debus, R. (2002). Developing deep learning approaches and personal teaching efficacy within a preservice teacher education context. British Journal of Educational Psychology, 72(4), 483-511.

Göktepe-Yıldız, S. ve Özdemir, A. Ş. (2018). Ortaokul öğrencilerinin matematik öğrenme yaklaşımlarının belirlenmesi. Ilkogretim Online, 17(3). 1378-1401.

Göktepe-Yıldız, S. (2019). Tasarım temelli matematik uygulamalarının farklı öğrenme yaklaşımlarına sahip ögrencilerin uzamsal yeteneklerine ve 3 boyutlu geometrik düşünme becerilerine etkisinin incelenmesi (Yayımlanmamış Doktora Tezi). Marmara Üniversitesi, Eğitim Bilimleri Enstitüsü, İstanbul.

Holton, D., \& Gaffney, M. (1994). Teaching talented students. In J. Neyland (Eds.), Mathematics education: A handbook for teacher, (pp. 397-409). Wellington, New Zealand: Wellington College of Education.

Horn, C. (2002). Raising expectations of children from poverty. Gifted Education Press Quarterly, 16 (4), 2-5.

İlhan, M., Çetin, B. ve Kılıç, A. M. (2013). Matematik öğrenme yaklaşımları ölçeği'nin (MÖYÖ) geliştirilmesi: Geçerlik ve güvenirlik çalışması, Bartın Üniversitesi Eğitim Fakültesi Dergisi, 2(2), 113-145.

Karasar, N. (2006). Bilimsel araştırma yöntemi. Ankara: Nobel Yayın Dağıtım.

Kontaş, H. (2010). Learning strategies of gifted elementary students. Elementary Education Online, 9(3), 11481158.

Lee, M., Johanson, R. E. \& Tsai, C. (2008). Exploring Taiwanese high school students' conceptions of and approaches to learning science through a structural equation modeling analysis. Science Education, 92, 191220.

Marton, F., \& Saljo, R. (1976). On qualitative differences in learning -II: Outcome as a function of the learner's conception of the task. British Journal of Educational Psychology, 46, 115-127.

Matic, L. J., Matic, I., \& Katalenic, A. (2013). Approaches to learning mathematics in engineering study program. Mathematics teaching for the future, 186-195.

MEB (2007). Millî Ĕ̆itim Bakanlı̆̆ Bilim ve Sanat Merkezleri Yönergesi. Tebliğler Dergisi.Ankara.

Mills, C. J. (1993). Personality, learning style and cognitive style profiles of mathematically talented students. European Journal for High Ability, 4, 70-85.

Offir, B., Lev, Y., \& Bezalel, R. (2008). Surface and deep learning processes in distance education: Synchronous versus asynchronous systems. Computers \& Education, 51, 1172-1183.

Oğuz, A., ve Karakuş, G. (2017). Öğretmen adaylarının öğrenme yaklaşımları ile kaygı düzeyleri arasındaki ilişkinin incelenmesi, Journal of Human Sciences, 14(2), 1831-1847.

Ozan, C., Köse, E. ve Gündoğdu, K. (2012). Okul öncesi ve sınıf öğretmenliği öğrencilerinin öğrenme yaklaşımlarının incelenmesi. Eğitim Bilimleri Araştırma Dergisi, 2(2), 75-92.

Öner, Y. İ. (2008). Ortaöğretim ögrencilerinin ögrenme yaklaşımlarını etkileyen faktörler (İstanbul örneği) (Yayımlanmamış Yüksek Lisans Tezi). Yeditepe Üniversitesi, Sosyal Bilimler Enstitüsü, İstanbul. 
Özgür, H., ve Tosun, N. (2012). Öğretmen adaylarının derin ve yüzeysel öğrenme yaklaşımlarının çeşitli değişkenler açısından incelenmesi. Mehmet Akif Ersoy Üniversitesi Eğitim Fakültesi Dergisi, 12(24), 113125.

Özkan, G., \& Sezgin-Selçuk, G. (2014). Determining the approaches of high school students to learning physics. Necatibey Faculty of Education Electronic Journal of Science \& Mathematics Education, 8(1), 101-127.

Öztaşkın, B. Ö. (2014). Sosyal bilgiler dersinde powerpoint sunum destekli öğretimin akademik başarıya ve öğrenme yaklaşımlarına etkisi. Adlyaman Üniversitesi Sosyal Bilimler Enstitüsü Dergisi, 7(17), 285-320.

Palanc1, M. (2004, Eylül). Üstün yetenekli öğrencilerin ihtiyaçlarını karşılamaya yönelik gerçeklik terapisi temelli okul rehberlik ve psikolojik danışma hizmetleri modeli. I. Türkiye Üstün Yetenekli Çocuklar Kongresi, İstanbul.

Pourselami, A., Erfani, N., \& Firoozfar, I. (2013). Mathematics anxiety, mathematics performance and gender differences among undergraduate students. International Journal of Scientific and Research Publication, $3(7), 1-6$.

Ramsden, P. (2000). Learnig to teaching in higher education. London: Newyork Routhladge Falmer.

Ravenna, G. (2008). Factors influencing gifted students' preferences for models of teaching. University of Southern California: ProQuest Dissertations Publishing, California.

Reid, W. A., Duvall, E. \& Evans, P. (2007). Relationship between assessment results and approaches to learning and studying in year two medical students. Medical Education, 41, 8, 754-762.

Renzulli, J.S., \& Reis, S, M. (1985). The school wide enrichment model: A comprehensive plan for educational excellence. Mansfield Center, CT: Creativ Learning Press.

Renzulli, J.S. (1999). What is thing called giftedness, and how do we develop it? A twenty-five year perspective. Journal for the Education of Gifted, 23 (1), 3-54.

Renzulli, J. S., Rizza, M. G., \& Smith, L. H. (2002). Learning styles inventory-version III: Ameasure of student preferences for instructional techniques. Technical and administration manual. Creative Learning Press, Mansfield.

Richardson, J. T. E. (1993). Gender differences in responses to the approaches to studying inventory. Studies in Higher Education, 18, 3-13.

Scouller, K. (1998). The influence of assessment method on students' learning approaches: Multiple choice question examination versus assignment essay. Higher Education, 35(4), 453-472.

Senemoğlu, N. (2011). College of education students' approaches to learning and study skills. Education and Science, 36(160), 65-80.

Severiens, S., \& ten Dam, G. (1997). Gender and gender identity differences in learning styles. Educational Psychology, 17, 79-93.

Sezgin-Selçuk, G., ve Ellez, M. (2002, October). Öğretmen adaylarının ögrrenme yaklaşımları. V. Ulusal Fen ve Matematik Eğitimi Kongresi’nde sunulan bildiri. Orta Doğu Teknik Üniversitesi. Ankara.

Sezgin- Selçuk, G. S., Çalışkan, S. ve Erol, M. (2007). Fizik öğretmen adaylarının öğrenme yaklaşımlarının değerlendirilmesi. Gazi University Journal of Gazi Educational Faculty (GUJGEF), 27(2), 25-41.

Sezgin-Selçuk, G. (2010). The effects of problem-based learning on pre-service teachers' achievement, approaches and attitudes towards learning physics. International Journal of the Physical Sciences, 5(6), 711723.

Sisk, D. A. (1990). The state of gifted education: toward a bright future. Music Educators Journal, 76 (7), 3539.

Smith, N. S., \& Miller, R. J. (2005). Learning approaches: Examination type, discipline of study, and gender. Educational Psychology, 25(1), 43-53.

Sowell, E. J., Zeigler, A. J., Bergwell, L., \& Cartwright, R. M. (1990). Identification and description of mathematically gifted students: A review of empirical research. Gifted Child Quarterly, 34, 147-154.

Spencer, K. (2003, September). Approaches to learning and contemporary accounting education. Paper presented at the Changing Environment Conference, Salford.

Stuart T. ve Beste, A. (2011). Farklı olduğumu biliyordum: Üstün yeteneklileri anlayabilmek. Ankara: Kök yayincilik.

Tinker, R. (1997). Information technologies in science and mathematics education reform in math and science education: Issues for classroom. Columbus, OH: Eisenhower National Clearing House.

Trigwell, K., \& Prosser, M. (1991). Improving the quality of student learning: the influence of learning context and student learning on learning outcomes. Higher Education, 22, 251-266.

Tural-Dinçer, G. ve Akdeniz, A. R. (2008, August). Fizik öğretmen adaylarının mesleki algı ve kaygıları. VIII. Ulusal Fen ve Matematik Kongresi'nde sunulan bildiri. Bolu Abant İzzet Baysal Üniversitesi Eğitim Fakültesi, Bolu.

Ünal, G. ve Ergin, Ö. (2006). Buluş yoluyla fen öğretiminin öğrencilerin akademik başarılarına, öğrenme yaklaşımlarına ve tutumlarına etkisi. Türk Fen Eğitimi Dergisi, 3(1), 1-17.

Von Glasersfeld, E. (1996). Introduction: Aspect of constructivism. In Catherine T. Fosnot, (Ed.), Constructivism: theory, perspectives and practice (pp. 3-7). New York: Teacher College. 
Yildiz, A., Baltaci, S., Kurak, Y., \& Güven, B. (2012). Examining the usage of problem-solving strategies by the eighth grade gifted and non-gifted students. Journal of Uludag University Faculty of Education, 25(1), 123143.

Yıldız, Y. (2015). Müzik öğretmeni adaylarının ders çalışma yaklaşımlarının akademik beklentileri açısından incelenmesi. Akademik Sosyal Araştırmalar Dergisi, 3(10), 400-414.

Zakaria, E., \& Nordin, N. M. (2008). The effects of mathematics anxiety on matriculation students as related to motivation and achievement. Eurasia Journal of Mathematics, Science \& Technology Education, 4(1), 27-30.

Watkins, D. (2001). Correlates of approaches to learning: A cross-cultural metaanalysis. In R.J. Stenberg, \& 1. Zhang (Eds.), Perceptives on thinking, learning and cognitive styles (pp.165-195). London: Lawrence Erlbaum Associates, Publishers.

Watkins, D. (1996). The influence of social desirability on learning process questionnaires: A neglected possibility?. Educational Psychology, 52, 260- 263.

Watkins, D., \& Mboya, M. (1997). Assessing the learning processes of black South African students. Journal of Psychology, 131, 623-640.

Wilson, K., \& Fowler, J. (2005). Assessing the impact of learning environments on students' approaches to learning: Comparing conventional and action learning designs. Assessment \& Evaluation in Higher Education, 30(1), 87-101. 